\title{
Workshops on Climate Smart Agriculture in Algeria
}

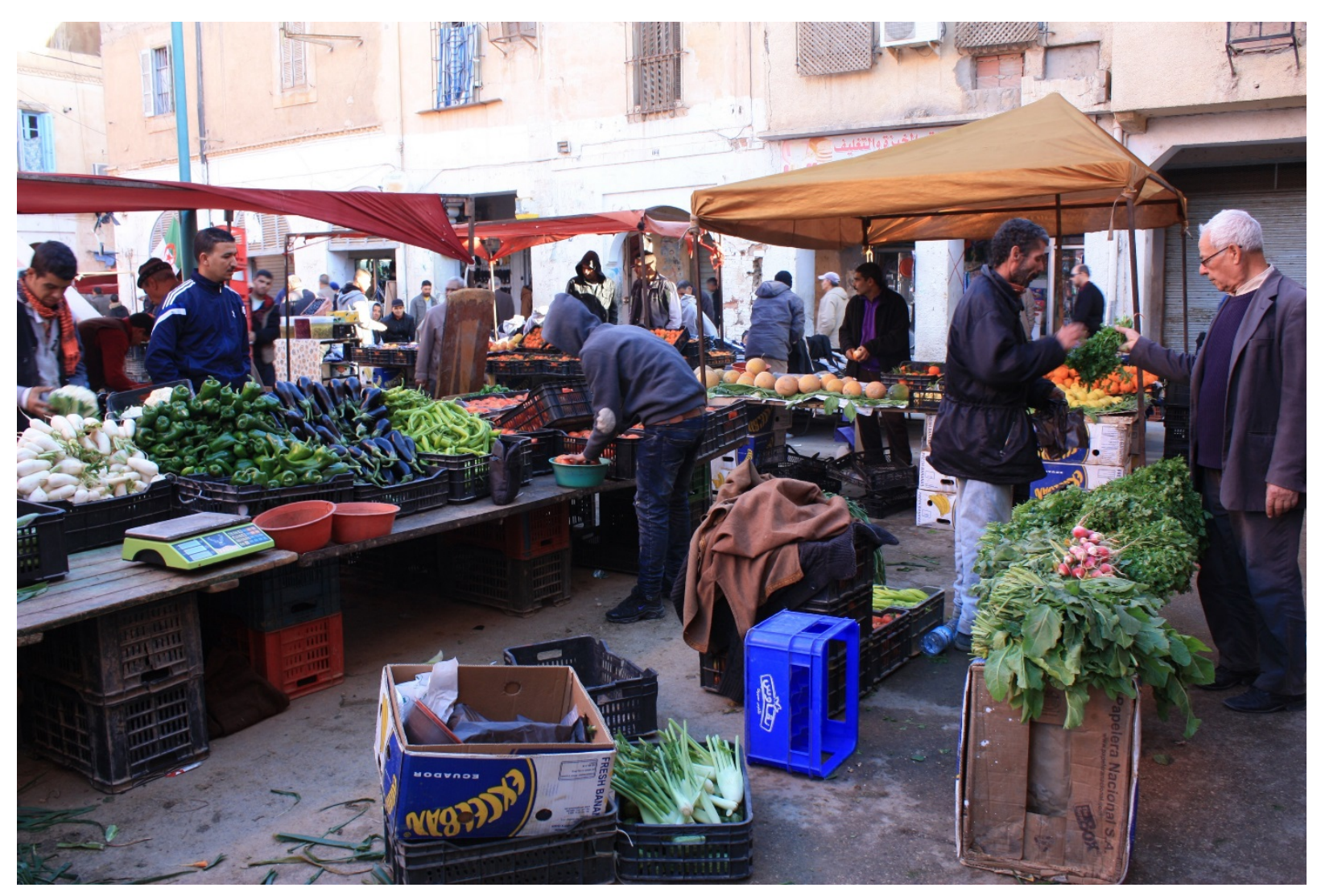

Greet Blom-Zandstra \& Anne Elings

Wageningen University \& Research

This study was carried out by the Wageningen Research Foundation (WR) business units Agrosystems Research and Greenhouse Horticulture and was commissioned and financed by Rijksdienst voor Ondernemend Nederland in the context of Policy Support. Project title: Workshops Climate Smart Agriculture (Mak17ALG01).

WR is part of Wageningen University \& Research, the collaboration of Wageningen University and Wageningen Research Foundation.

Wageningen, November 2017

Report WPR - 721 
Blom-Zandstra, G. \& A. Elings, 2017. Workshops on Climate Smart agriculture in Algeria. Wageningen Research, Report WPR - 721; pp. 32; 7 fig.; 2 ref.

Keywords: Climate Smart Agriculture, Algeria, greenhouse technology, potato production

This report can be downloaded for free at https://doi.org/10.18174/444735

(C) 2017 Wageningen, Stichting Wageningen Research, Wageningen Plant Research, Business Unit Agrosystems Research, P.O. Box 16, 6700 AA Wageningen, T +31 (0)317 487231 ; Business Unit Greenhouse Horticulture, P.O. Box 644, 6700 AP Wageningen; T +31 (0)317 485606 ;

Chamber of Commerce no. 09098104 at Arnhem

VAT NL no. 8065.11.618.B01

Stichting Wageningen Research. All rights reserved. No part of this publication may be reproduced, stored in an automated database, or transmitted, in any form or by any means, whether electronically, mechanically, through photocopying, recording or otherwise, without the prior written consent of the Stichting Wageningen Research.

Stichting Wageningen Research is not liable for any adverse consequences resulting from the use of data from this publication.

Report WPR - 721

Photo cover: G. Blom-Zandstra 


\section{Contents}

$\begin{array}{ll}\text { Summary } & 5\end{array}$

$\begin{array}{lll}1 & \text { Introduction } & 7\end{array}$

$\begin{array}{lll}1.1 & \text { Visit and workshops } & 7\end{array}$

2

$\begin{array}{ll}\text { Presentations at the SIMA fair } & 9\end{array}$

2.1 The Dutch approach to greenhouses, Anne Elings 9

2.2 Climate Smart Agriculture, Greet Blom 9

3

$\begin{array}{ll}\text { Field visits } & 11\end{array}$

3.1 Biskra 11

3.1.1 Greenhouse production systems 11

3.1.2 Université Mohamed Khider (El Biskra) 13

$\begin{array}{lll}3.2 \text { El Oued } & 14\end{array}$

$4 \quad$ Results, opportunities and follow up $\quad 16$

$\begin{array}{llr}5 & \text { References } & 17\end{array}$

$\begin{array}{lll}\text { Annex } 1 & \text { Programme of the visit } & 18\end{array}$

$\begin{array}{lll}\text { Annex } 2 & \text { Presentations } & 19\end{array}$ 


\section{Summary}

Algeria copes with serious negative effects of Climate change, with water scarcity as the major hazard. Due to this climate change, the country copes with a very serious water scarcity problem in regions that are responsible for the highest agriculture production in the country. Therefore, it becomes crucial to implement a more adapted agriculture with regard to the climate changes, and the use of more advanced technological solutions to limit the climate effect on productivity. Herewith, Algeria might benefit from the Dutch advanced knowledge on this matter.

During a visit of two experts from WUR, workshops were held to present and demonstrate that with the adoption of Climate Smart Agriculture, farmers might be able to limit and control the effects of climate change on agriculture, so securing more productivity with less resources. The focus of the workshops was on greenhouse technology and on the production of potatoes.

For the workshops on greenhouse technology, the Dutch approach to greenhouse design was presented. This design tries to realize a greenhouse production system in which environmental and economic sustainability are optimized. Resource use efficiency in greenhouse production systems is substantially higher than in open fields.

For the workshops on sustainable potato production, the just started project on sustainable water use for potato production in El Oued, was presented. In the project, Wageningen University \& Research will cooperate with the Universities of El Oued, Biskra and Ouargla. During a visit to El Oued, after the workshops, it was discussed how we can make our cooperation between the universities work.

In this report, the results of the workshops and meetings are presented. 


\section{$1 \quad$ Introduction}

At the moment, Algeria is going through very obvious climate changes, with colder winters and hotter summers. Due to this climate change, the country copes with a very serious water scarcity problem in regions that are responsible for the highest agriculture production in the country. This will affect the future productivity of the entire agricultural sector. Therefore, it becomes crucial to implement a more adapted agriculture with regard to the climate changes, and the use of more advanced technological solutions to limit the climate effect on productivity. This new techniques may enable farmers to limit and control the effects of climate change on agriculture, so securing more productivity with less resources. Herewith, Algeria might benefit from the Dutch advanced knowledge on this matter.

From October $10^{\text {th }}$ till $13^{\text {th }}, 2017$, the SIMA fair (SIMA SIPSA) took place in Algiers. Generally, a lot of farmers from the Maghreb visit the fair, presenting an excellent momentum to demonstrate and discuss Climate Smart Agriculture techniques in a Maghreb context in order to:

- Inform the Algerian and Maghreb audience on the impact of climate change on the production in the agriculture sector,

- Prove to smallholders that an adoption of a climate smart solution will mitigate the effect of Climate Change, and

- $\quad$ Create awareness on the need of the adoption of climate smart solutions in order to limit the climate impacts on agriculture production.

Therefore, a visit was organized for two experts from WUR in company with the Agricultural Counsellor for the Magreb (Nico Visser) and employees from the Netherlands Embassy in Algiers (Tahar Maza and Khaled Benchaalal).

\section{Visit and workshops}

In Algeria, the production of potatoes is one of the most important commodities, with a total area of 156.176 ha and a yearly production of almost $5 \mathrm{Mt}$. Currently, potato production is still unsustainable and much can be gained in terms of water use efficiency, fertilizer and pesticides applications, $\mathrm{CO}_{2}$ footprint, field layout, the choice of appropriate varieties, the quality of the starting material and prevention of post-harvest losses. This year, a demonstration project started on Sustainable Water use in potato, which is a combined activity of Algerian and Netherlands public, private and research parties, with the aim to test and illustrate the innovative technique of underground fertigation (i.e. a combination of drip irrigation and fertilization) and how it can contribute to more sustainable water use practices. Crop production in greenhouses, having good perspectives in terms of Climate Smart Agriculture, is coming up in Algeria, but still in a preliminary phase of development.

During this visit, the focus was on potato production and greenhouses and contained two elements:

1a) Two days workshops during the SIMA-SIPSA fair:

- Presentation and demonstration of another way to irrigate potatoes in the Algerian desert in order to sustain potato production and optimize the productivity of natural resources;

- Presentation of and discuss an environmentally and economically sustainable method to realize a greenhouse project that meets the requirements of the crop, the climate, fits within an economic commercial model and gives growers the tools to cultivate desired greenhouse crops regardless under Algerian climate conditions.

1b) Two days field visits:

- A workshop with presentations on 'Sustainable Dutch Greenhouse Design' and on 'Sustainable Potato Growing' in Biskra, in cooperation with the University of Biskra and the private sector participating via the Agricultural Chamber Biskra, organized by Tahar Maza, Agricultural Assistant of the Netherlands Embassy Algiers.

- A meeting and presentation on 'Sustainable Potato Growing' in El Oued in cooperation with the University of El Oued and the University of Ouargla and the private sector via the potato growers cooperative, organized by Khaled Benchaalal, senior economic adviser of the Netherlands Embassy Algiers. 
Concrete aims of the visit were:

- Proving to the Algerian and Maghreb audience that with the adoption of a climate smart solution, they will be able to, at least, limit and control the effects of climate change on agriculture, so secure more productivity with less resources.

- The small farmers will be informed about the climate impact on the production in the agriculture sector (potatoes and greenhouse) and start to realize the need to start taking measures towards adopting climate smart solutions in order to limit the climate impacts on agriculture production.

The programme of the visit is presented in Annex 1. 


\section{Presentations at the SIMA fair}

\subsection{The Dutch approach to greenhouses, Anne Elings}

The Dutch approach to greenhouse design tries to realize a greenhouse production system in which environmental and economic sustainability are optimized. Environmental sustainability can be quantified in terms of the total use and efficiency of the use of water, energy, nutrients, crop protection agents and other inputs. Resource use efficiency in greenhouse production systems is substantially higher than in open fields. Economic sustainability can be quantified in terms of production, investment costs, running costs and pay-back period. Modules that together constitute a greenhouse construction and installation are combined to achieve this (Elings et al., 2015). Van Os et al. (2012) conducted such an analysis for Algerian conditions, in particular those around Algiers and Biskra.

Starting point of the design process is the crop that requires optimal conditions of temperature, $\mathrm{CO}_{2}$, light quantity and quality, water and nutrients and must be well-protected against pests and diseases. Optimal conditions vary over crops and, to a lesser extent, also varieties. Management is very important and requires much knowledge on the crop and the greenhouse - this is why knowledge transfer is such an important issue in the establishment of a greenhouse sector.

Design of the greenhouse for Algerian conditions focuses on temperature control and irrigation. Temperature can be controlled through ventilation, use of covering material, shading, heating during cold nights and active cooling. For irrigation, a strategic choice has to be made between drip irrigation if the crop is grown in the soil and soilless cultivation.

First recommendations for single tunnels are:

- Enlarge the ventilation openings along the sides of the greenhouse to $30 \%$

- Use diffuse film with high light transmission.

- $\quad$ Introduce pad \& fan cooling in Biskra where summer temperatures are too high

First recommendations for Canarian and multispan greenhouses are:

- $\quad$ Realize $30 \%$ ventilation rate

- Use insect nets

- Consider heating and heat storage

- $\quad$ Use a fogging system in a high greenhouse

The entire presentation is given in Annex 2 .

\subsection{Climate Smart Agriculture, Greet Blom}

Global climate change is both resulting from agricultural activities (due to its emission of greenhouse gasses) as affecting agriculture by its negative impact on crop production. For Algeria, main hazards of climate change are an increase of water scarcity, heat waves and the incidence of extremes (i.e. sand storms). Climate Smart Agriculture is an appropriate way to tackle Climate Change, aiming at securing food production, adaptation in agriculture and mitigation of greenhouse gasses. For Algeria, water conservation strategies are most needed, which may comply: smart irrigation strategies by sophisticated scheduling, introduction of innovative equipment and precision techniques and by breeding for drought tolerant and water efficient cultivars.

Recently, a new project has started on sustainable water use for potato production in El Oued, the largest potato production area of the country in which potato growing practices are rather unsustainable. In this project, a real-live situation on a 5 hectares demonstration farm will be set up, 
aiming at: Introduction of mechanization at planting and harvest; saving water extraction and irrigation by monitoring and control; lowering the $\mathrm{CO} 2$ footprint; optimization of the supply of fertilizer and pesticides; introduction of better varieties and development of a national roll-out plan for scaling up. Farmers and other stakeholders will be involved from the beginning by regular farm visits and workshops. Results from similar projects in other countries of the arid zone give rise to expect beneficial results from this demo project as well due to substantial water savings, decreased costs and increased production levels. To convince farmers to adopt the innovative farm management strategies, data on different characteristics of the potato crop growth (water use, fertilization needs, harvest, etc.) will be collected and discussed with the participants of the visits and workshops.

In the project, Wageningen University \& Research will cooperate with the Universities of El Oued, Biskra and Ouargla. Therefore, a Memorandum of Understanding between the universities has come into effect, which will enable the strengthening of the working relation within the project and the exchange of scientific knowledge between Algeria and the Netherlands.

The entire presentation is given in Annex 2. 


\section{$3 \quad$ Field visits}

\subsection{Biskra}

\subsubsection{Greenhouse production systems}

Upon arrival to Biskra on Saturday November $15^{\text {th }}$ 2017, the group was welcomed at the airport by $\mathrm{Mr}$. Guemari Massoud, President of the 'Chambre d'Agriculture Wilaya de Biskra' and by its General Secretary Ghemri Mohomed Fonzi. The cooperation ${ }^{1}$ is with 6200 members and an annual turnover of $€ 15$ million the largest of Algeria and responsible for the coordination and introduction of innovative activities within the agricultural sector. Its members grow a wide variety of crops (for example, 24,000 ha cereals) and hold cattle such as sheep (wool for carpets, meat) and camels. The cooperation knows about 6000 ha of greenhouses in which mostly beef tomatoes are grown - in the soil. Cherry tomatoes are gaining attention. The beef tomatoes are traded on the domestic market. Approximately $90 \%$ of the greenhouses are of the tunnel type, but the share of Canarian greenhouses is increasing.

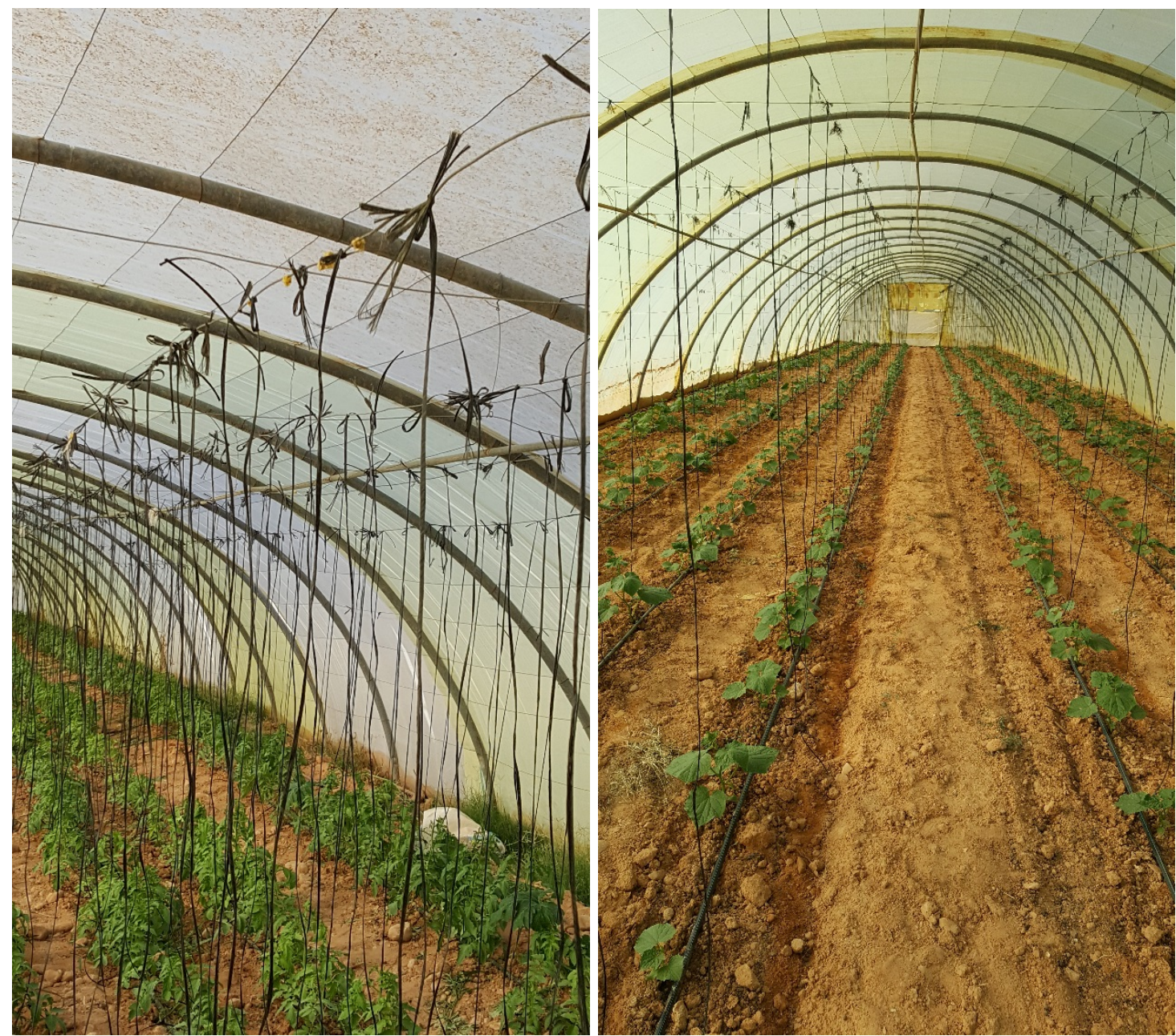

Figure 3.1 Inside views of a tunnel greenhouses recently planted with tomato.

The tunnel greenhouses are technologically very simple: soil cultivation, NPK application, drip irrigation with thin tubes and with drippers that are not pressure-regulated, only ventilation at the

\footnotetext{
${ }^{1}$ See http://www.vitaminedz.org/fr/Biskra/Directions-et-chambres-d-agriculture/20010/1.html
} 
ends of the tunnel, no nets. Estimates of yield levels vary between 5-10 kg fresh $\mathrm{m}^{-2}$. The greenhouses (that is, only the construction, the plastic cover is renewed) are transferred to a new location every three years to deal with soil-borne diseases. Each farmer possesses one or a few greenhouses, but assist other farmers in their activities. Although the level of technology and yields are very low, it appears that the system is economically profitable because of the low investments and operational costs.

However, water use efficiency is low, which is a major concern for the region of Biskra where annual precipitation is estimated at $<250 \mathrm{~mm}$ (van Os et al., 2012) and where sub-surface water is pumped for free. Also, because of the high summer temperatures and poor ventilation of the tunnel greenhouses, crop cultivation in that period is not possible. Thirdly, land use is inefficient because of the periodic transfer of the greenhouse construction to avoid problems with soil-borne diseases (it is unknown after which period land can be re-used again).

The few Canarian greenhouses were not visited.

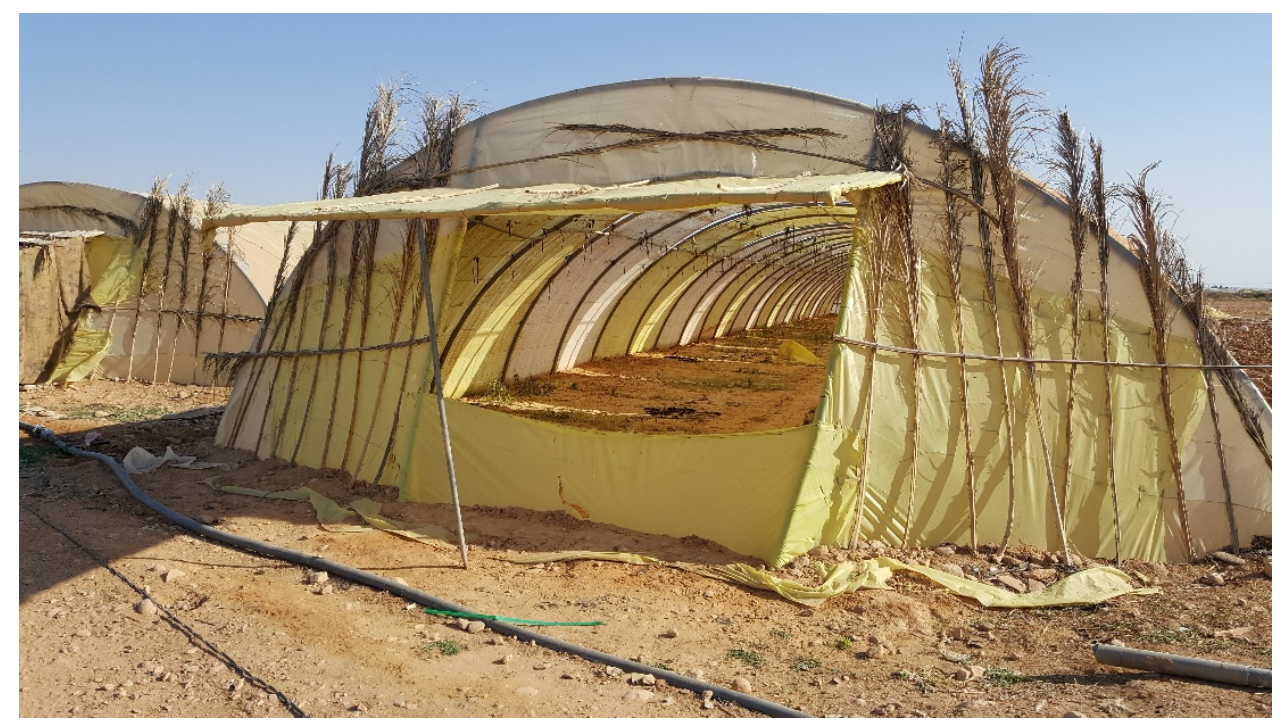

Figure 3.2 Outside view of a tunnel greenhouses standing empty.

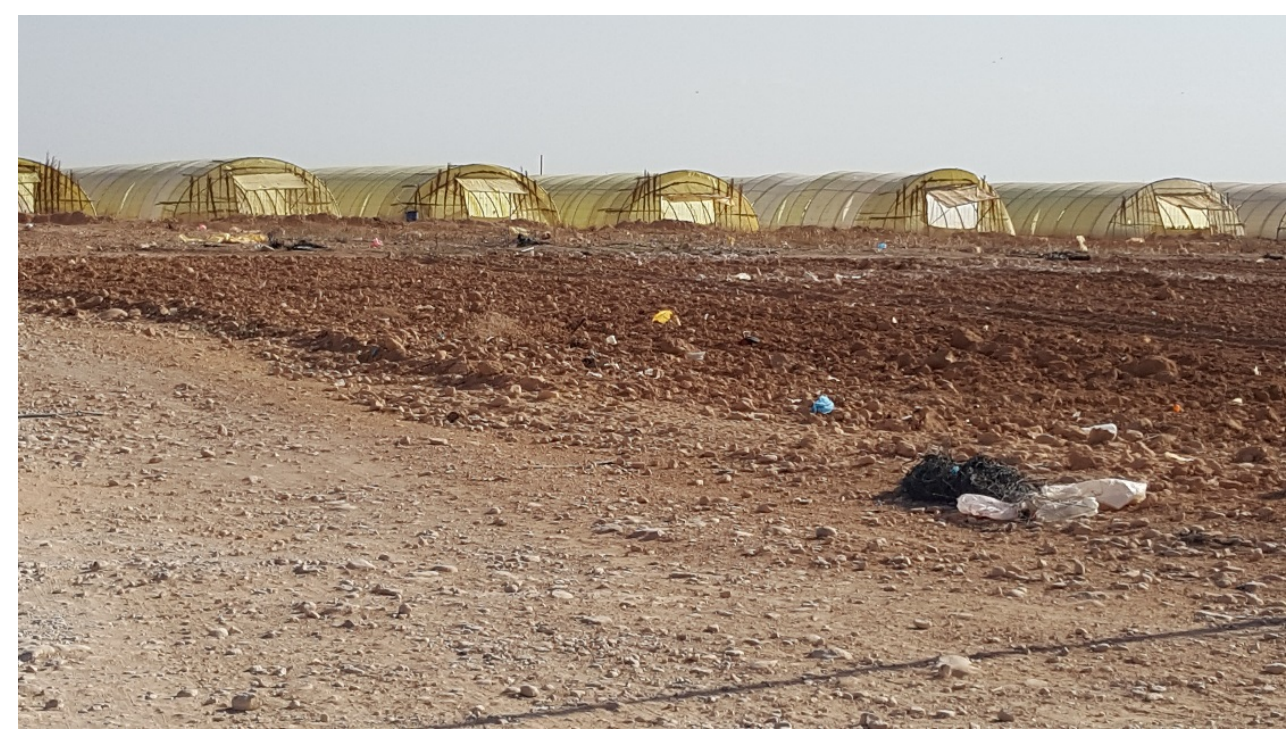

Figure 3.3 A group of tunnel greenhouses. They are transferred every three years to a new location, in order to deal with soil-borne diseases. 


\subsubsection{Université Mohamed Khider (El Biskra)}

In the morning of Sunday November $16^{\text {th }}$ 2017, presentations were given the Université Mohamed Khider at El Biskra (see Annex 2). These presentations were very well attended, with ca 120 academics, students and farmers. A fair number of farmers and farm leaders participated in the discussion and gave brief overviews of their production system and problems they were dealing with.

In Biskra no arable farming is done. So potato production systems are no major issues here.

Responding to the presentation on Climate Smart Agriculture following comments were made:

- $\quad$ The concept should have a well sound economic business model.

- Why is the project on sustainable potato farming situated in El Oued?

- What are the main problems? This comment was replied by an explanation on the current unsustainable farm management systems and the need for a development towards a more sustainable approach as water availability is expected to become limited in the near future.

With regards to greenhouse production systems the major issues were:

- How can production be increased?

- What are technological options?

- Can a demo centre be established?

- Can key data be collected (for which already farmers volunteered).

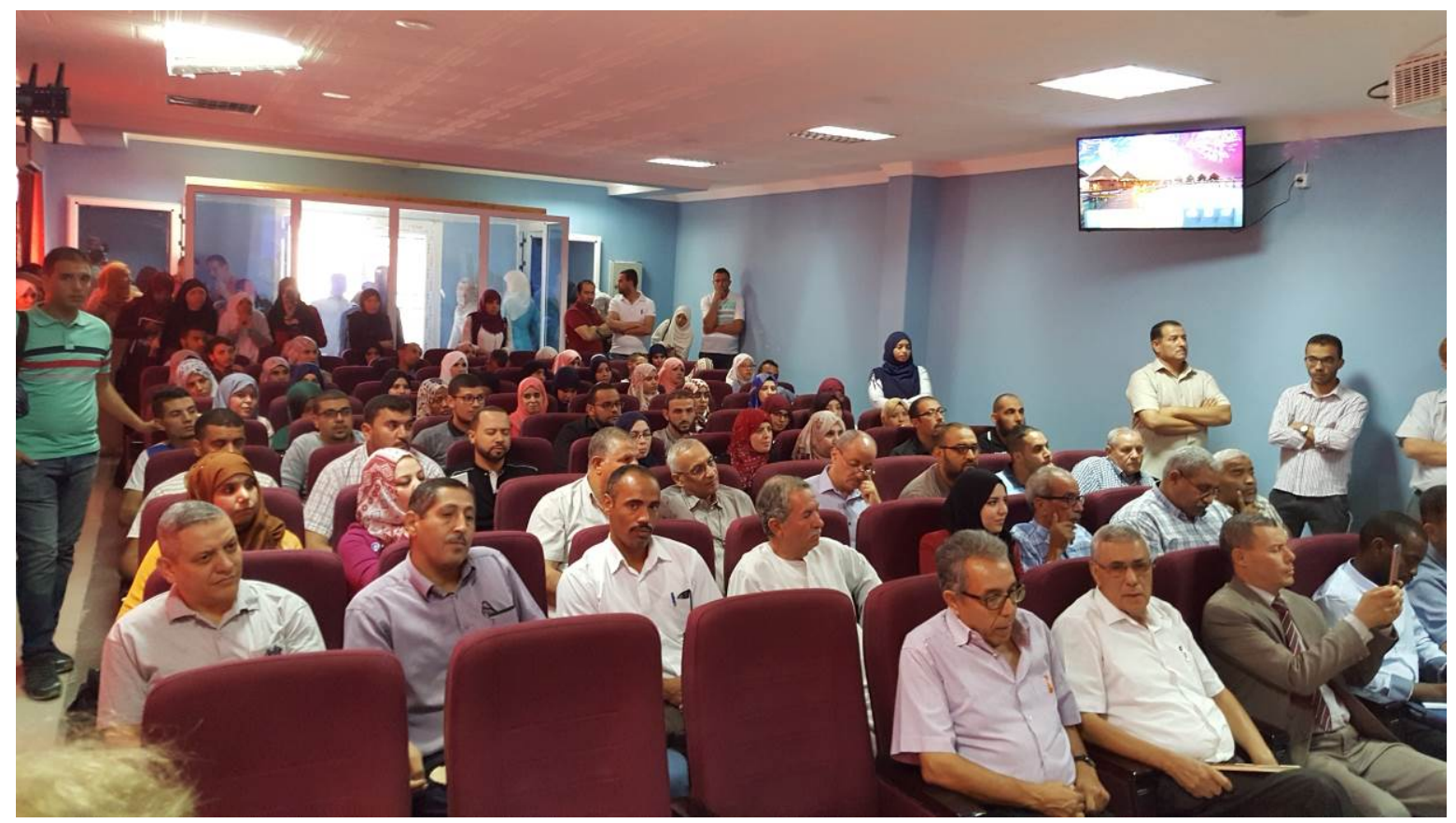

Figure 3.4 An audience of ca 120 academics, students and farmers during the presentations at El Biskra University.

In the afternoon, strategic collaboration between the Universities of El Biskra, El Oued and Ouargla. These three universities have a recently signed Memorandum of Understanding with the Plant Research Group of Wageningen University and Research. Within this MoU, collaboration on potatoes has been commenced, and collaboration on protected horticulture can be established.

The following was agreed upon:

- $\quad$ For Wageningen UR, Dr. Greet Blom will be contact person.

- $\quad$ For the Algerian Universities, Prof. Dr. Mahmoud Debabech will be contact person.

- The MoU is focussing on potato production, but attention to and knowledge exchange on other crops will be added in our cooperation in the long run. The attention for horticulture during this mission is already a first effort in broadening of the cooperation programme.

- Operationalisation of the MoU: A clear division of labour between universities (with concrete protocol) and communication plan will be made (coordination: Khaled Benchaalal) 
- Dr. Anne Elings will write a discussion paper on greenhouses (a wide range of priorities were identified).

- J Jint development of research proposals will be pursued. EU-tenders may also be interesting in this context.

- Summaries of the presentations will be send via Tahar Maza.

- A discussion on amounts of water availability in Aquifers will be setup by e-mail with Soadi Hossina.

\section{$3.2 \quad$ El Oued}

At Monday October $16^{\text {th }}$, Tahar, Khaled and Greet visited the university of El Oued. Approximately 90 participants (of which $>80 \%$ were female!) attended the meeting. Presentations were given by Greet (see annex 2) and Dr. Abdelmalek Zaater on the demonstration project and its objectives. It was emphasized that Algeria is the largest potato producer in the Magreb, the second in ranking in Africa and the fifteenth worldwide. The farming systems suffer from erosion, soil acidity, soil pollution and increased water scarcity. Therefore, water and energy use - currently still highly inefficient - should become more sustainable. A regulation of prices by governmental intervention is needed (and expected). The university of El Oued works on an equilibrium model for sustainable crop production and towards a 'more crop per drop' approach. During the discussion it was stated that:

- $\quad$ within the cooperation between WUR and the Algerian universities an integrated approach is important.

- the water which is pumped up for irrigation of the potatoes has an EC (electrical conductivity) of $3.8 \mathrm{mS} / \mathrm{cm}$. A filter on the new equipment is needed.

Further, it was discussed how we make our cooperation between the universities work. Following appointments were made:

- Greet writes the protocols for the measurements on crop growth and crop water use in the field and send it to the contact persons (done already),

- $\quad$ Based on the protocols, the staff from the university will start with the measurements in a control field to become to build their skills,

- In the next season the scientists will train the students how to do the measurements,

- Regular communication (NL - El Oued) on the status of the art, progress, results, bottlenecks, etc. will be set up by weekly Skype meetings, starting at November $8^{\text {th }}$,

- The universities will list all participants in the project (professors, teachers, students) and the complementary specialties for each university involved in this partnership.

In the afternoon, the plot, intended to be used for the demonstration, was visited. The farmer mentioned that a drain with a depth of 35-40 m is being constructed. Next to the drip system, which will be introduce by Holland Machinery, a pivot system for the first wetting of the field is available, Electricity is available at the entrance of the field. 


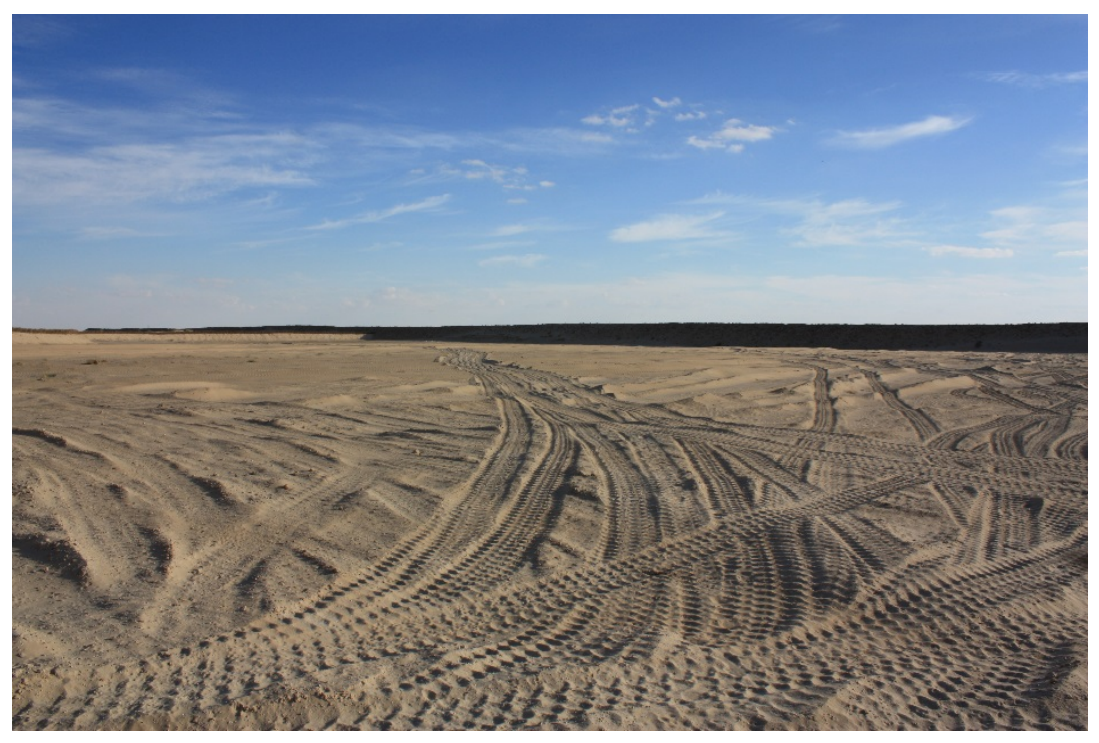

Figure 3.5 plot intended to be used for the demonstration field.

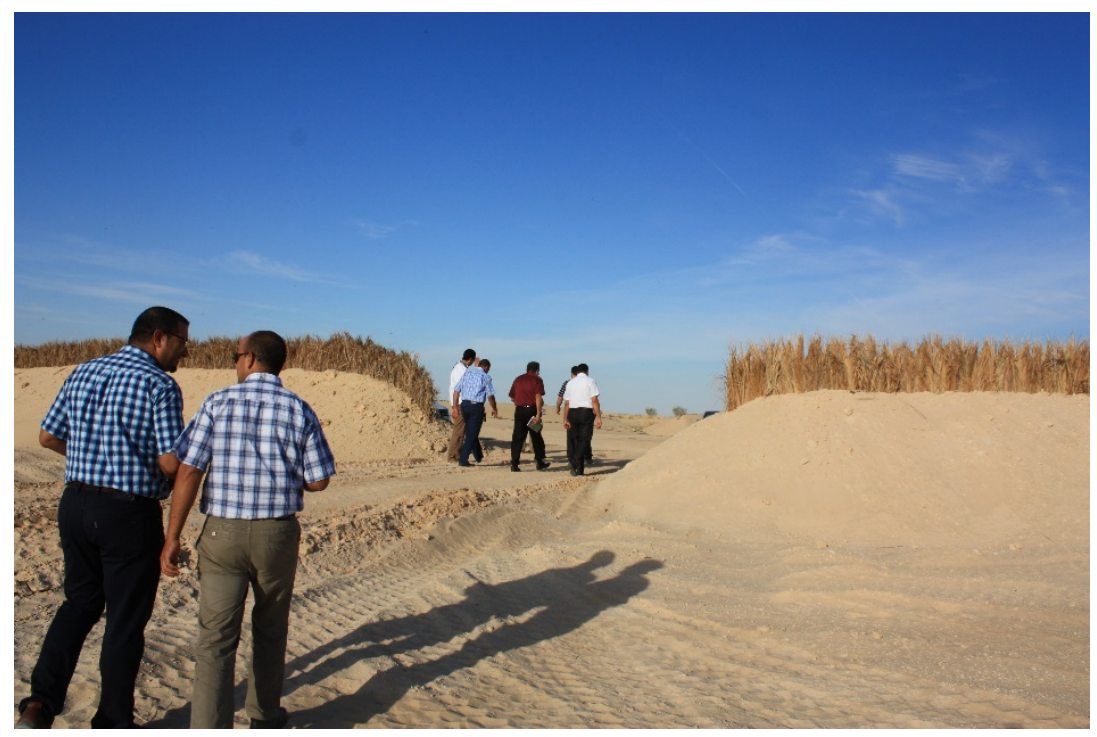

Figure 3.6 Entrance of the plot, intended for the demonstration field.

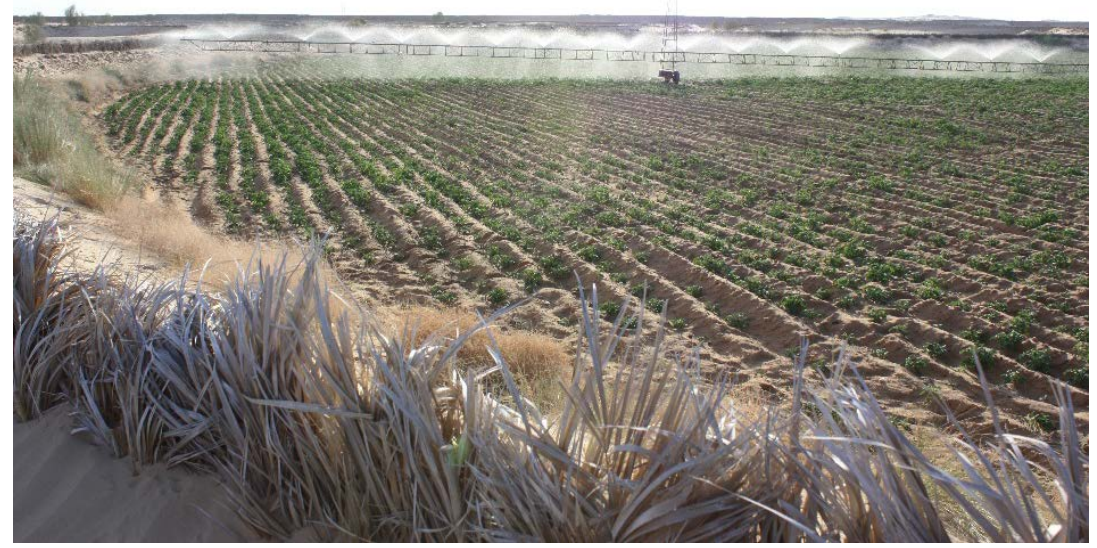

Figure 3.7 Control field adjacent to plot intended as demonstration field. 


\section{$4 \quad$ Results, opportunities and follow up}

\section{Results}

1) Increased awareness with Algerian stakeholders with regards to climate-smart solutions to current issues in potato and greenhouse production systems.

2) New and deepened contacts between The Netherlands and Algerian stakeholders.

3) Concrete appointments for the Sustainable Water Use project in El Oued.

\section{Opportunities}

1) J oint development of a greenhouse demonstration centre to serve the needs of the Algerian growers.

2) Joint research and education, in which both the private and public sector participate.

3) Collaboration with private enterprises such as Agro Tahraoui.

\section{Follow-up}

1) Writing protocols for the following up of the Sustainable Water use project in El Oued (Greet Blom)

2) Further implementation of the above mentioned project activities (Greet Blom)

3) Development of (an outline for) a proposal for a demonstration centre and academic collaboration in the field of protected horticulture. Share outline with Mr. Nico Visser and subsequently elaborate and discuss with Algerian stakeholders. Anne Elings.

4) Identify needs of Agro Tahraoui and proceed accordingly. Anne Elings.

5) Develop discussion paper on academic collaboration in the field of protected horticulture. Anne Elings. 


\section{$5 \quad$ References}

Elings, A., S. Hemming, S. Bakker, E. van Os and J. Campen, 2015. The African Greenhouse. A toolbox. Wageningen UR Greenhouse Horticulture Report GTB-1360, http://edepot. wur.nl/351439.

Os, E. van, B. Speetjens, M. Ruijs, M. Bruins and A. Soupanas, 2012. Modern, sustainable, protected greenhouse cultivation in Algeria. Wageningen UR Greenhouse Horticulture Report GTB-1263, http://edepot. wur.nl/280136. 


\section{Annex 1 Programme of the visit}

\begin{tabular}{|c|c|c|c|}
\hline Participants & Greet, & co, Anne, Khaled and Tahar & \\
\hline Date & Hour & Activity & who \\
\hline $9-10-2017$ & & Arrival from Rabat to Algiers & Nico \\
\hline 10-10-2017 & 10:00 & Inauguration of Sima Sipsa & Nico And CdP \\
\hline 11-10-2017 & & Arrival from Netherlands to Algiers & Greet And Anne \\
\hline $12-10-2017$ & $\begin{array}{l}\text { Sima } \\
\text { Sipsa }\end{array}$ & Presentation (Climate smart agriculture) & Greet \\
\hline $12-10-2017$ & $\begin{array}{l}\text { Sima } \\
\text { Sipsa }\end{array}$ & $\begin{array}{l}\text { Presentation (The Dutch Approach to } \\
\text { Greenhouses) }\end{array}$ & Anne \\
\hline $12-10-2017$ & 19:00 & Evaluation dinner of Sima Sipsa & $\begin{array}{l}\text { Dutch companies } \\
\text { participating in Sima Sipsa }\end{array}$ \\
\hline 13-10-2017 & All day & Attending sima sipsa & All team \\
\hline 13-10-2017 & $17: 45$ & Departure to Biskra & All team \\
\hline 14-10-2017 & All day & Visit of horticultural farms & All team \\
\hline 15-10-2017 & 9:00 & Presentation (Climate smart agriculture) & Greet \\
\hline 15-10-2017 & $12: 00$ & Lunch & \\
\hline 15-10-2017 & 13:00 & $\begin{array}{l}\text { Presentation (The Dutch Approach to } \\
\text { Greenhouses) }\end{array}$ & Anne \\
\hline $15-10-2017$ & $17: 10$ & $\begin{array}{l}\text { Departure to Algiers and Morocco and the } \\
\text { Netherlands, respectively }\end{array}$ & Nico and Anne \\
\hline 15-10-2017 & 16:00 & Departure to El Oued by rental car & Greet - Khaled - Tahar \\
\hline 16-10-2017 & 9:00 & Presentation (Climate smart agriculture) & Greet \\
\hline 16-10-2017 & $12: 00$ & Lunch & \\
\hline 16-10-2017 & 13:00 & Visit Houideg Farm in El Oued & Greet - Khaled - Tahar \\
\hline 17-10-2017 & $6: 30$ & $\begin{array}{l}\text { Departure from el oued to Algiers and the } \\
\text { Netherlands }\end{array}$ & Greet - Khaled - Tahar \\
\hline
\end{tabular}




\section{Annex 2 Presentations}

This is the presentation given by Anne Elings in Biskra on October 15, 2017. The presentation in Algiers on October 13, 2017 was a shorter version. The economic example of greenhouses for Mexico were derived from an older presentation and has been added as an illustration in the absence of detailed information for the Algerian situation.
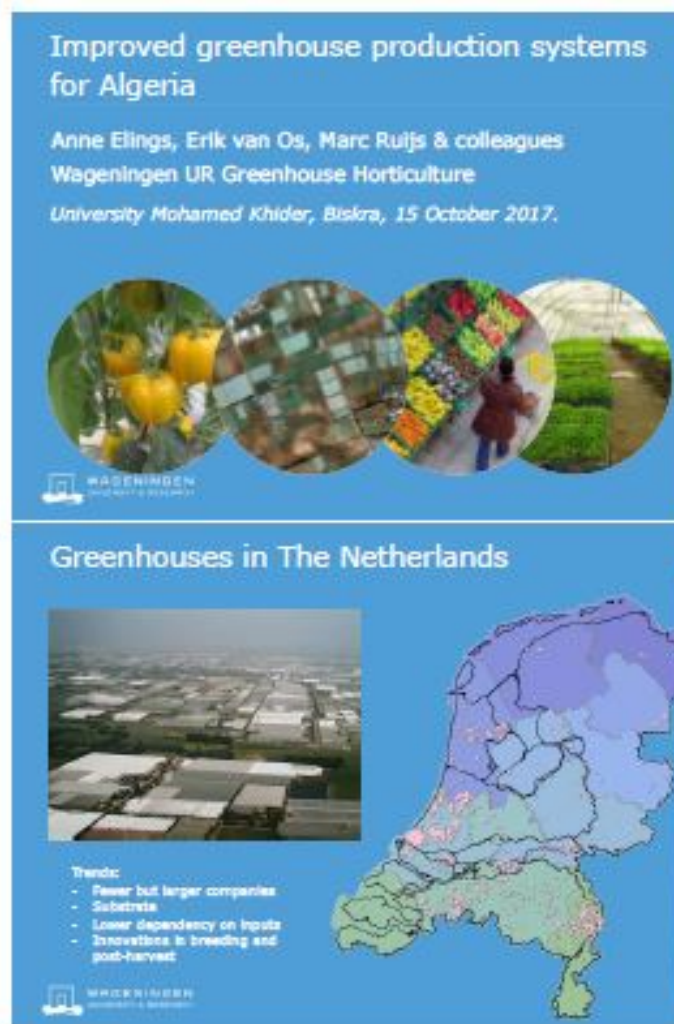

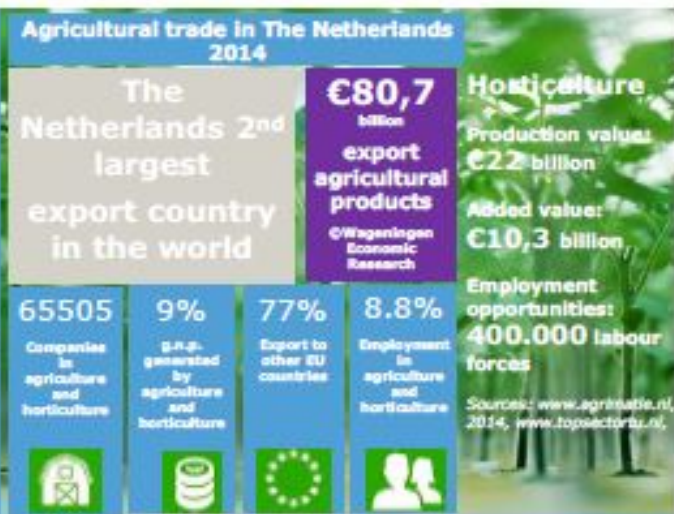

Priorities to increase food supply

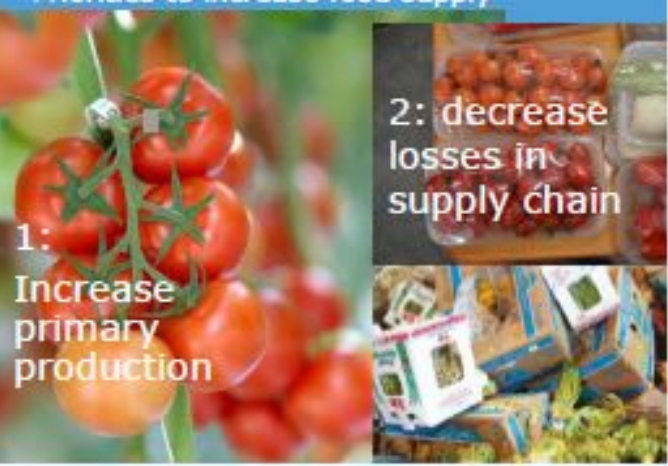

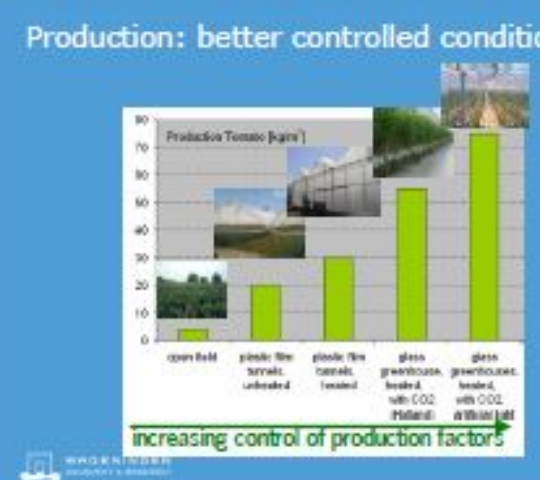

The issue

\section{- What does the best greenhouse production system for Algeril look tike? \\ - What does 'the best' mean? \\ - Envionmental sustahabiliny \\ - Whter use (omcleng) \\ - Energy use (eminciancy) \\ - Econsmk sustorabality}

- Production

- Imestment costa

- Mayback pertos
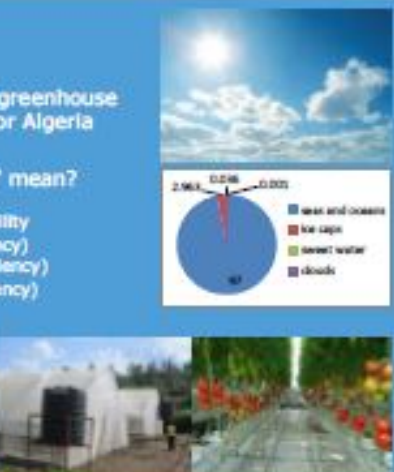

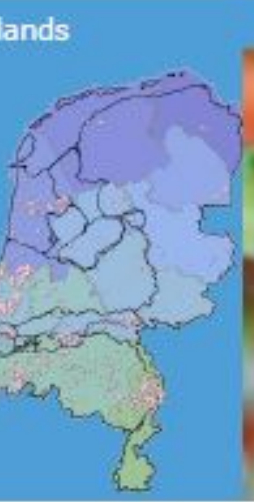

conditions

cised
Protected Horticulture: 15 times better resource efficiency

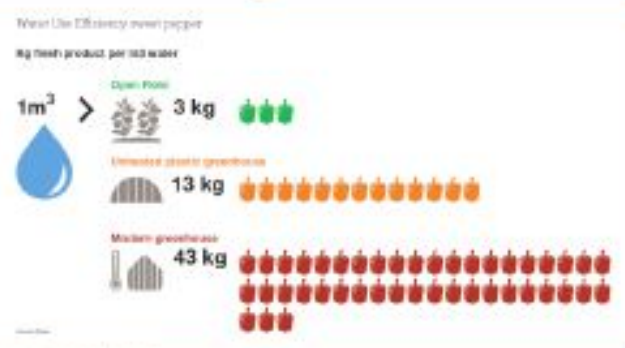

$\min$
Greenhouse inside

= Loht

$-\mathrm{CO}_{2}$

- Temperature

- Alr humidity

- Nutrients

- Water

- Pests \& Diseases

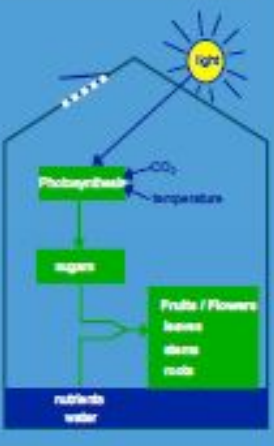




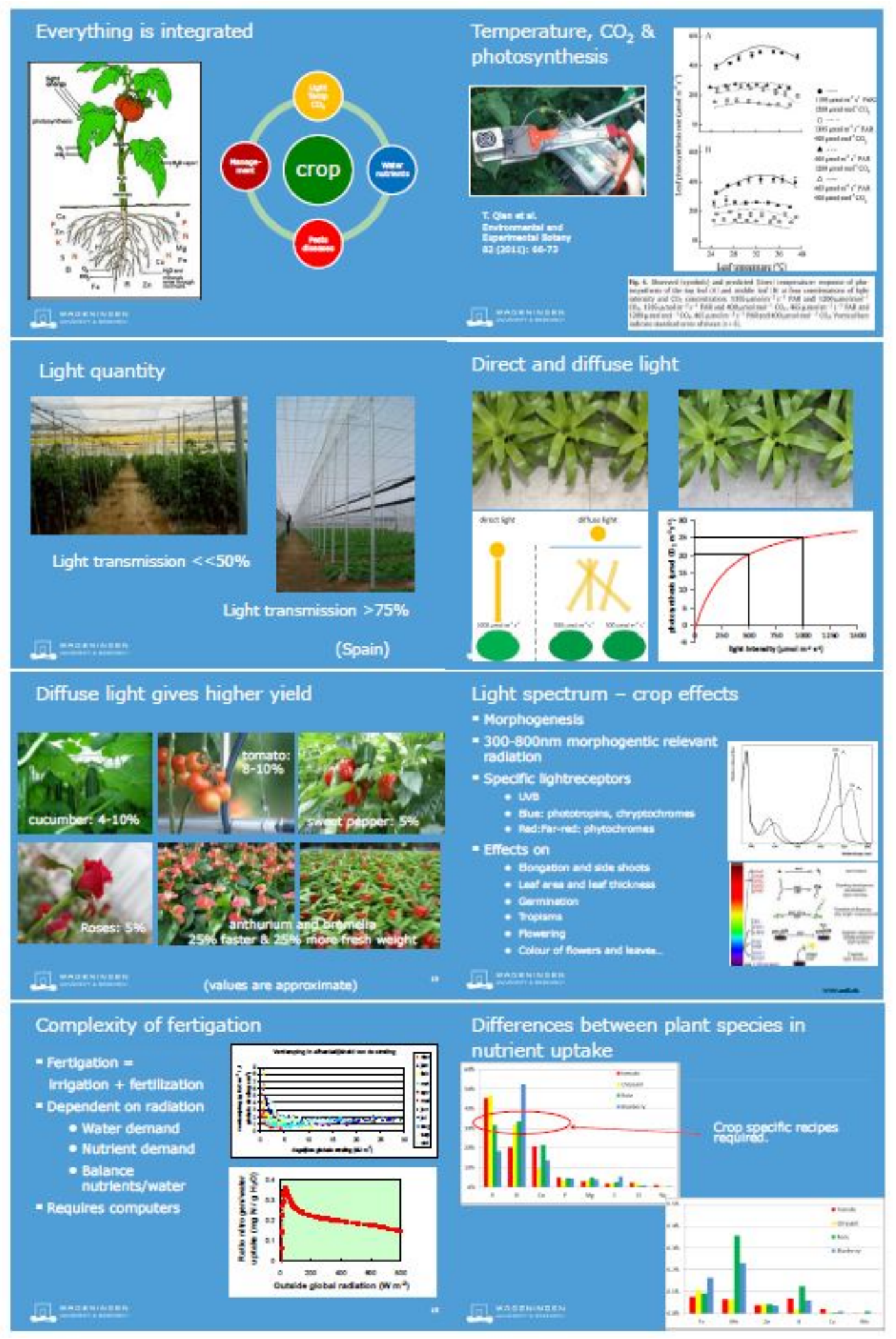




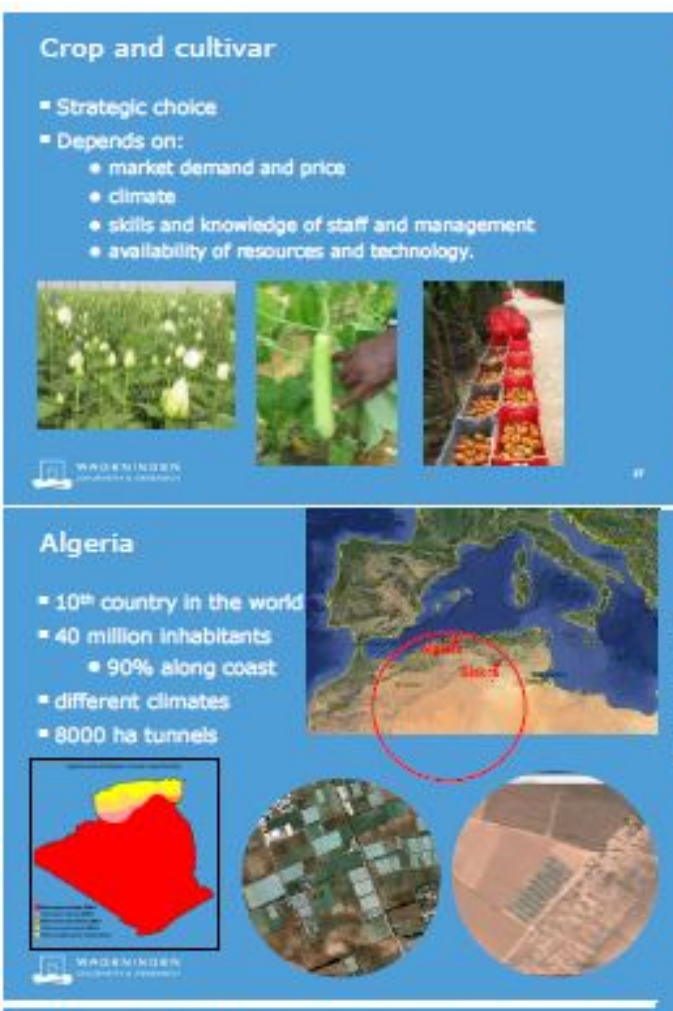

Management - Do not do this:
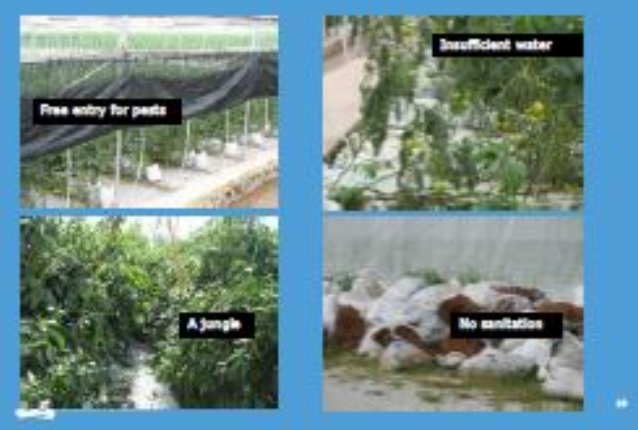

Algerian climate - global radiation

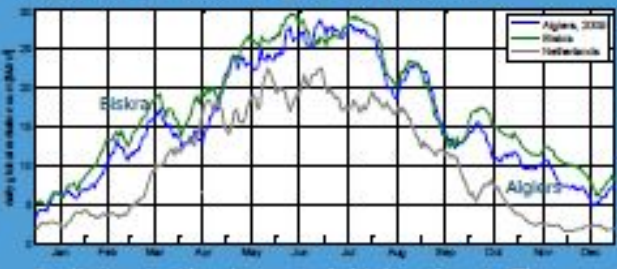

- Radiation in Algeria is much higher than in the Netheriands (6 vs $3.8 \mathrm{GJ}$ year

- higher yleids possible?

- In winter all light is needed inside the greenhouse 向

Algerian climate - humidity
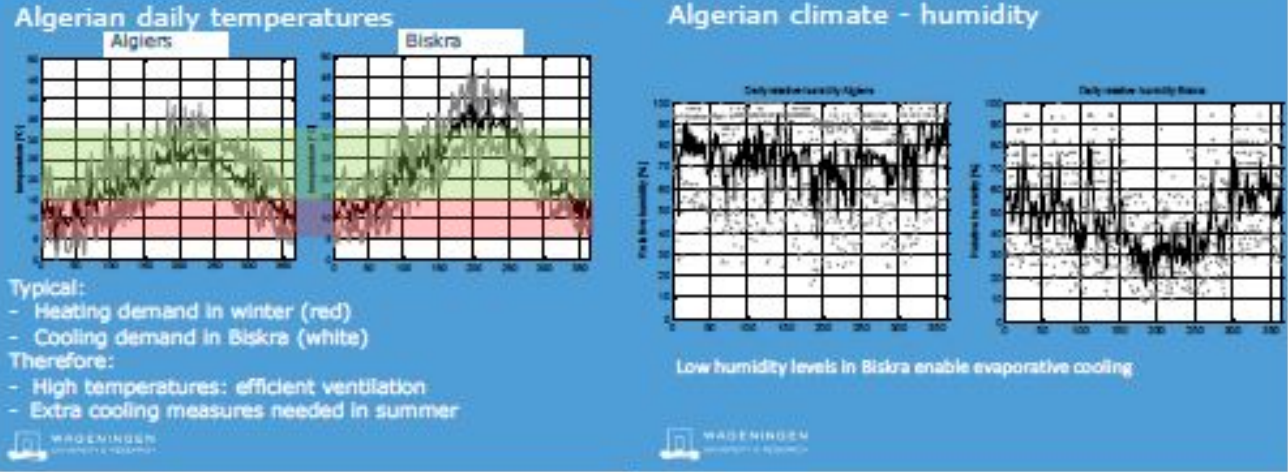

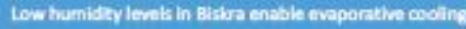
而, matuinose

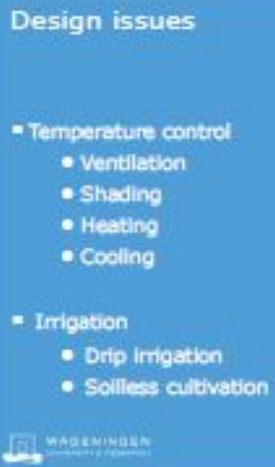

Single tunnels:

low ventilation, high temperature

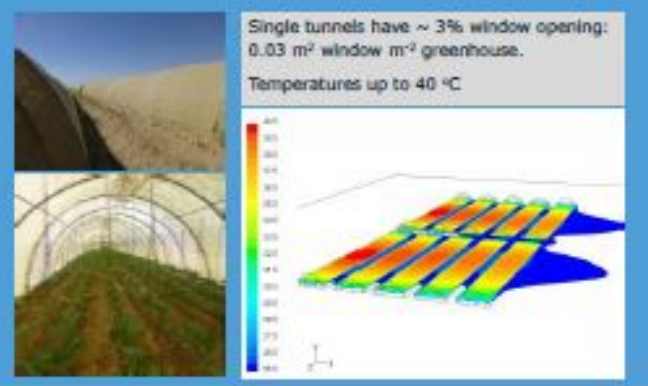




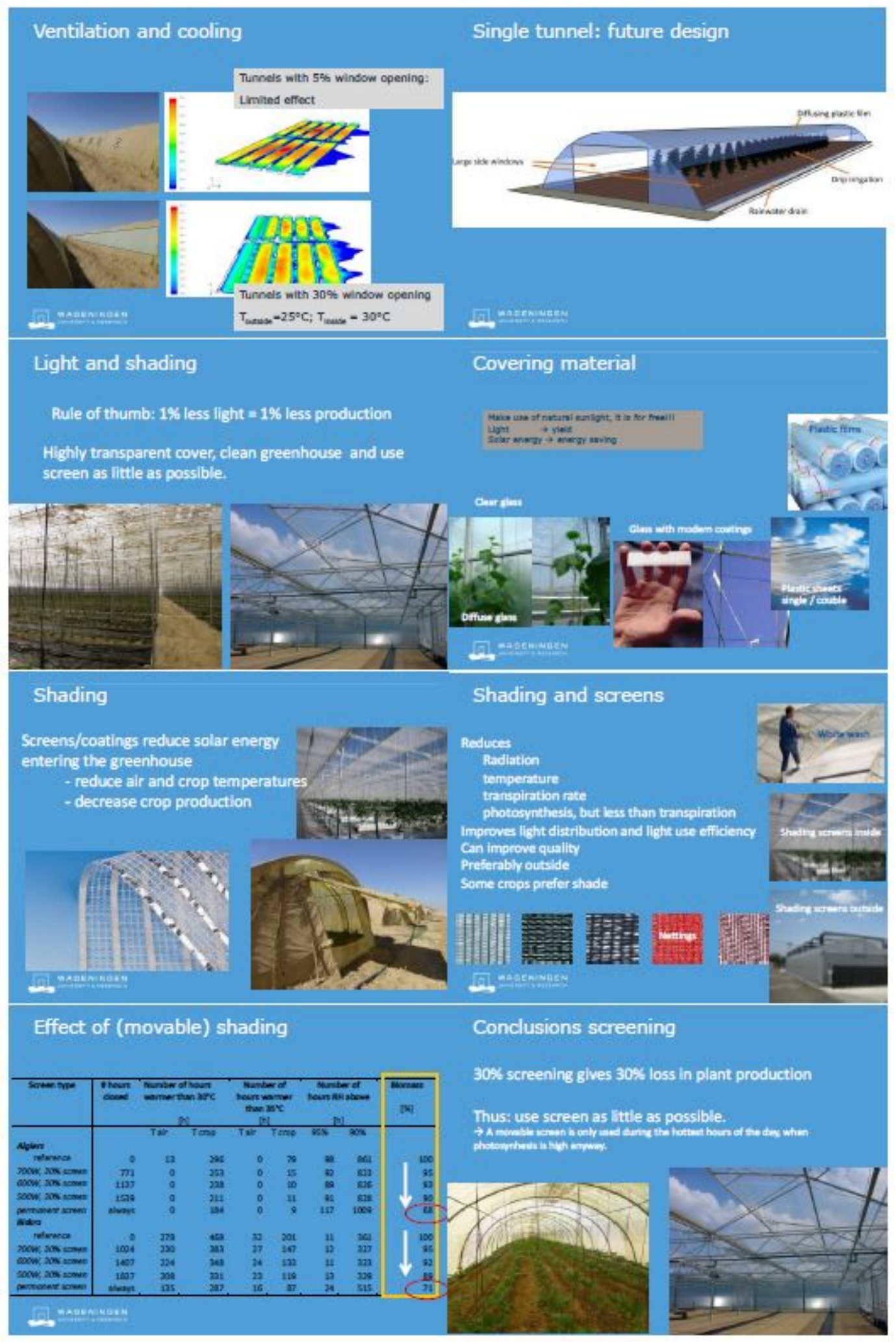




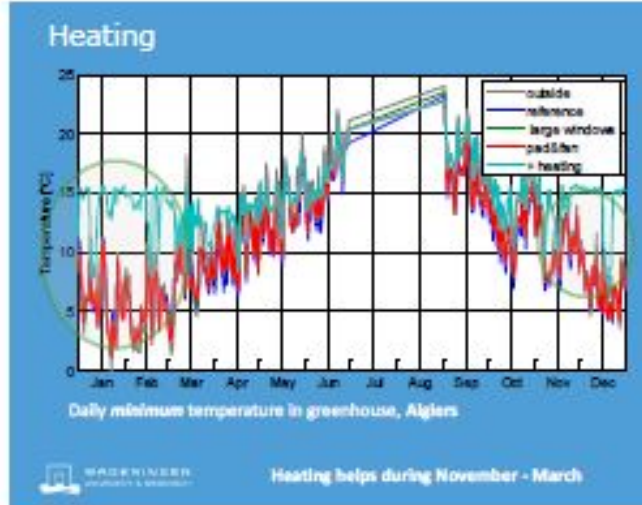

Evaporative cooling

- Misting / podsfan systems reduce the temperature $\rightarrow$ good for plants

- However:

- Expensive

- Hilgh water consumption

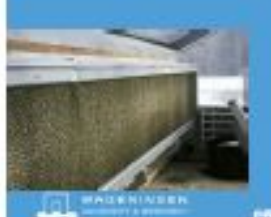

(6)

Rainwater collection

- Precipltation: 500-600 mm in coastal area

$-75 \%$ of water need

- $1000 \mathrm{~m}^{2} \mathrm{ha}^{-1}$

- Adapted single tunnel design

- Multispan collection is possible but not done
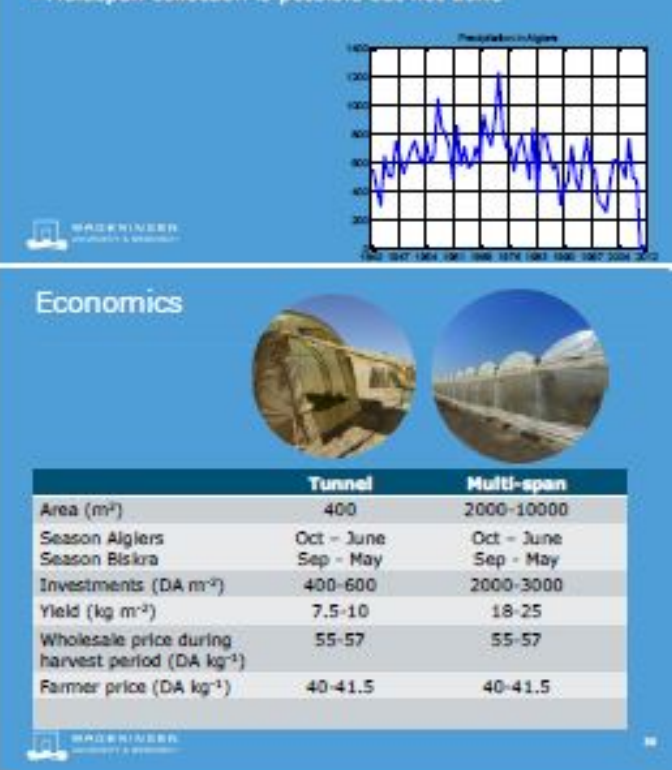

Heating

Natural gas is conventional technology Solar thermal could be interesting in Aferla

Always combined with eneray ecreen at night

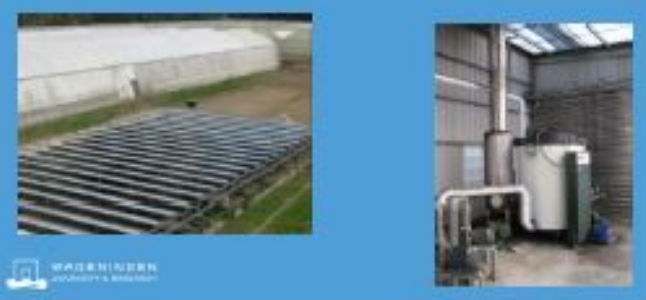

Water and nutrient supply
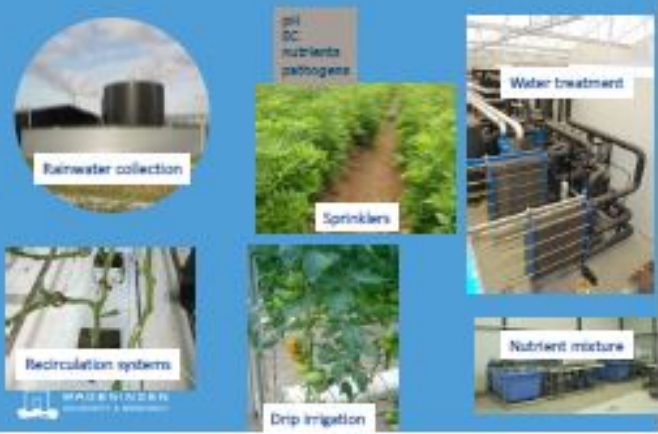

Hydroponic cultivation

- Soll borne diseases

- Solar radiation insuifident

- Change to hydroponics: $20 \%$ more yield

- Open system

- Reuse of surplus in other soll cultures

- Closed system

- disinfection required

- Slow sand fitration as cheap rellable option

- Local substrate

ต.

Improvements single tunnel

\begin{tabular}{|c|c|c|c|c|}
\hline & Abzien: & & Bsina & 56 \\
\hline & $\begin{array}{l}\text { Were } \\
\text { mindown }\end{array}$ & padsfan & $\begin{array}{l}\text { Larke } \\
\text { whinduss }\end{array}$ & tpadaftan \\
\hline $\begin{array}{l}\text { Estra investment } \\
\left(\mathrm{Um}^{2}\right)\end{array}$ & a.15 & 1.43 & 0.15 & 1.43 \\
\hline $\begin{array}{l}\text { Extra variablet } \\
\text { labour + equikment } \\
\left(\mathrm{C}_{\mathrm{m}} \mathrm{m}^{2} / \mathrm{v} \mid\right.\end{array}$ & $a .12$ & 0.6 & 0.08 & 0.6 \\
\hline Extra yield $\left(\mathrm{kd} / \mathrm{m}^{3}\right)$ & \pm & 15 & 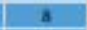 & 17 \\
\hline $\begin{array}{l}\text { Extra invenues } \\
\text { (G/m2) }\end{array}$ & 0.4 & 0.6 & a.s & a. \\
\hline \multicolumn{5}{|l|}{ extra grofn $(\mathrm{C} / \mathrm{m} 2 / \mathrm{M}$} \\
\hline Perbeck period (y) & eI & 39 & e1 & 3 \\
\hline
\end{tabular}




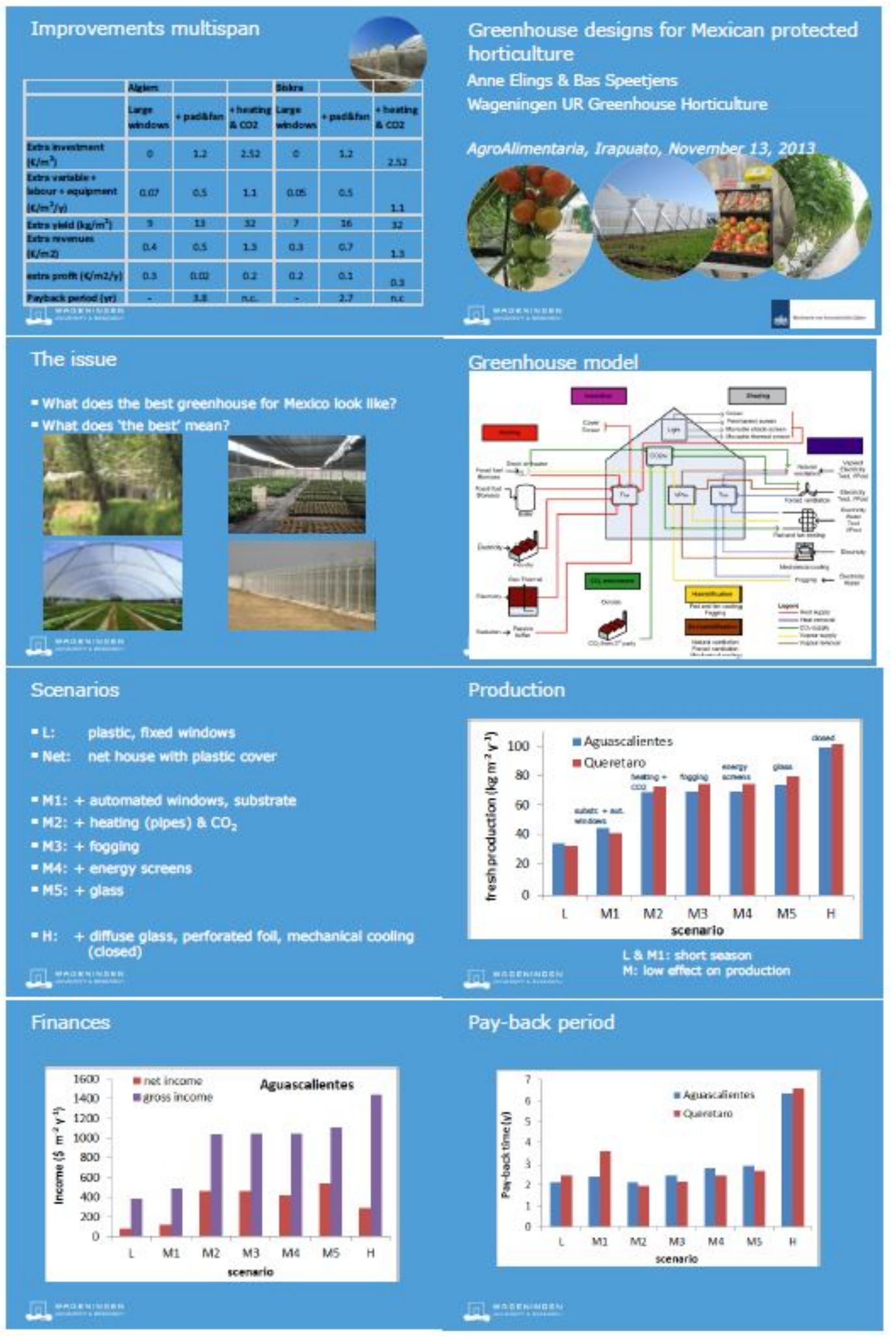


Different (financial) yield

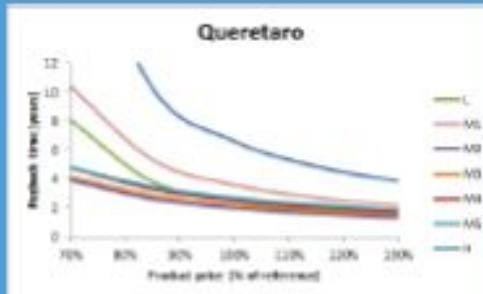

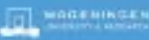

Summary Economics

- Mew designs improve economic results

- targo mindows show good results

- pad a fan syatem

ne inprovement of pron.

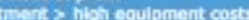

- Largo mindowst padaten thasting*CO, show best rasults in Biskn

- Payback perlod alugle span

- Lape whadsis: 1 year

- Larpe whodswa + padion 4.5 your

- Payback periad multicpen

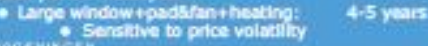

而,

\section{Conclusions applied to present types}

- Single tunnels: $8 \times 50 \times 3.2 \mathrm{~m}$

- $30 \%$ required, $50 \%$ production increase

- Pad a fan cooling: Biskra area, 10 oC lower T

- Difuse film with high light transmission

- Canartan and multispan greenhouse

- $30 \%$ ventilation rate required

- Insect nets (Tuta absoluta)

- Foogling system in high greenhouse

- Heating 8 heat storage?

同, eacounass

Thank you
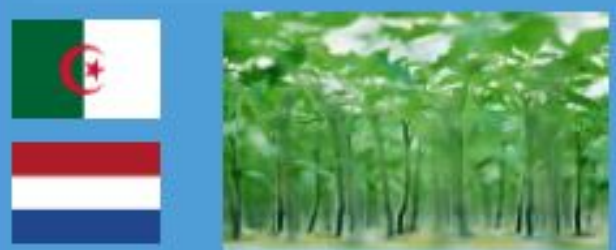

amesirngarst

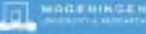

Muchas gracias

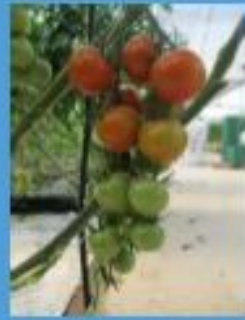

Muenesteven

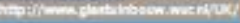

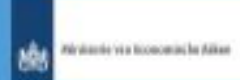

m, wasyuses:

Conclusions

- Ventlation

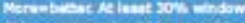

- Shading

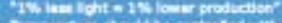

- Cooling (fogging/padeatan)

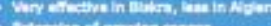

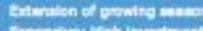

Heating

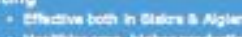

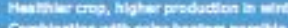

间, wayensus

Remaining issues

- Training, and more training

- Integrabed Pest a Disease

Management

- Crop husbandry

- Maintenance industry

= Ir structure; sensor technolooy

- Market intelligence

- Rules and leglisiation

. ... and mary more ...

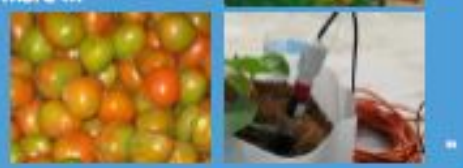

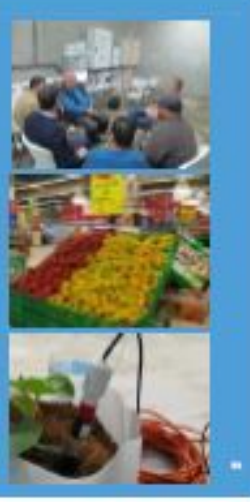

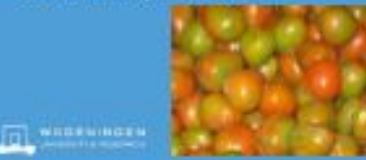

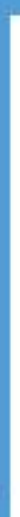


This is the presentation given by Greet Blom in El Oued. The presentations held in Algiers and Biskra contained some more general information on Climate Smart Agriculture, but less information on the running project on sustainable potato production.
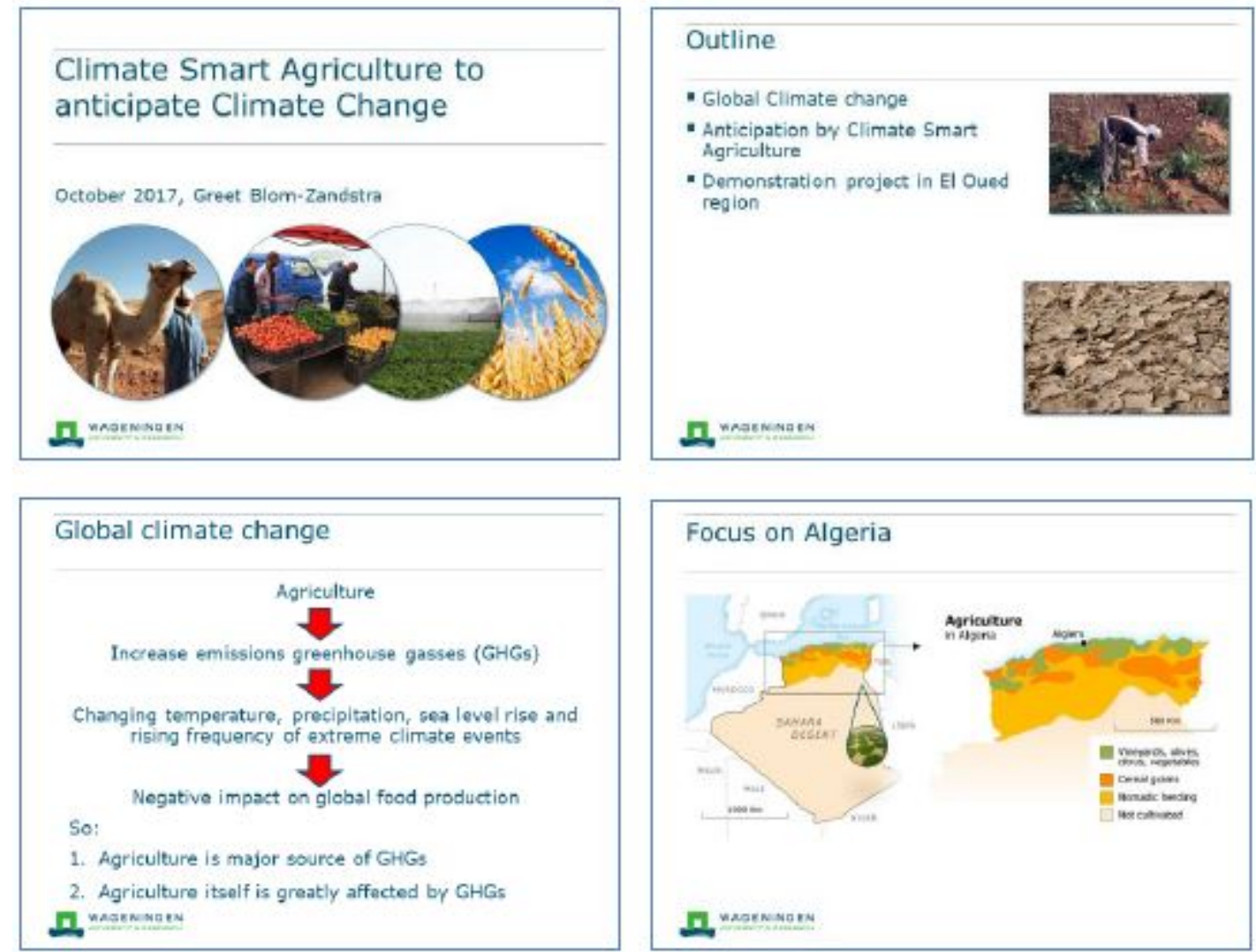

GHG emissions - total

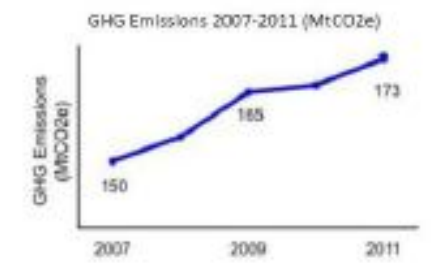

Ageria | 2015 Global Climate Legslation Study - haicatar

I. wasenes

Groundwater resources potential (high and middle Cheliff Basin)

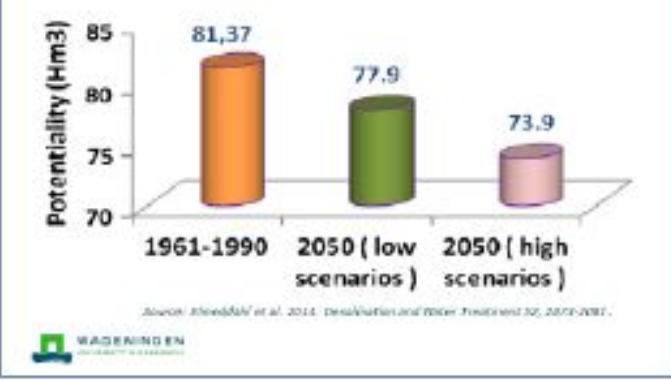

Annual variation of rainfall

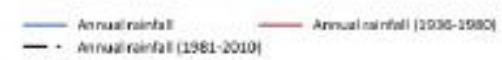

200

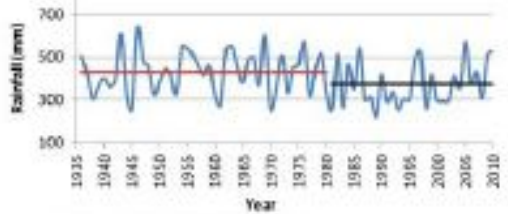

Station NMD of Chlof (1936-2010)

I. Wasensoren

Expected future trends in Algeria

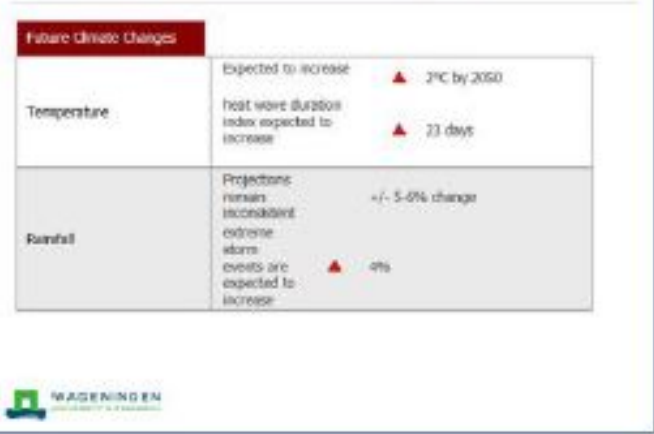



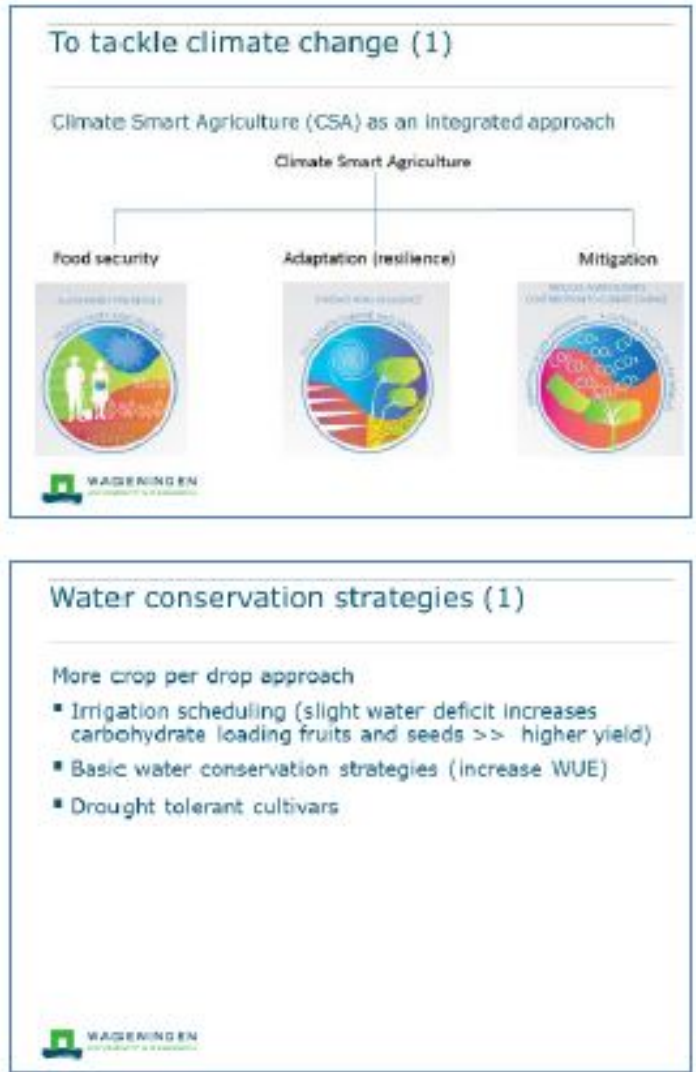

Demonstration project in El Oued region

El Oued Sustainable Water use for potato production project 2017-2019

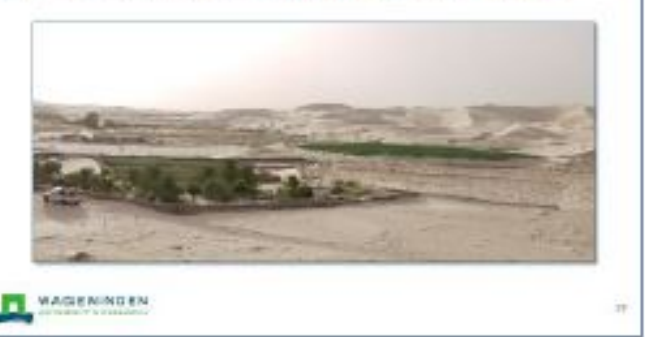

Current situation El Oued region
Current potato growing practices unsustainable
- Water extraction from non-renewable fussil water reserves
- Ineficlent water use by uncontrolled and wasteful coverhead
piwot irrigation
- Inadequate fertilication by hand spread and uncontrolled
supply
- Large variation in quality starting material
- Diseases (Erwinia, Rhizoctonla, Late and Early Blight, etc.)
D, wanksaev

\section{Mitigation measurements}

Management Carbon and Nitrogen flows

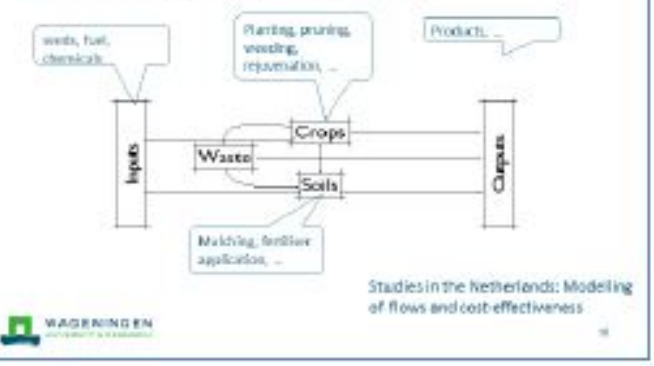

Water conservation strategies (2)

- Drip irrigation in stead of spriniclers

- Predision techniques (monitoring and contral) - Senser technology

- Computer controled system
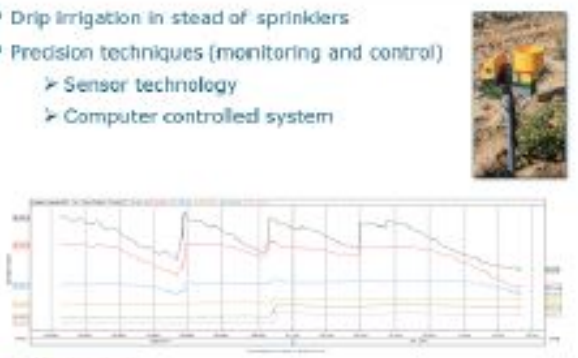

A.

\section{Current situation El Oued region}

- Important population centre (750.000 inhabitants)

- Largest potato production area (33.000 hectares)

- Two potato growing cycles per year
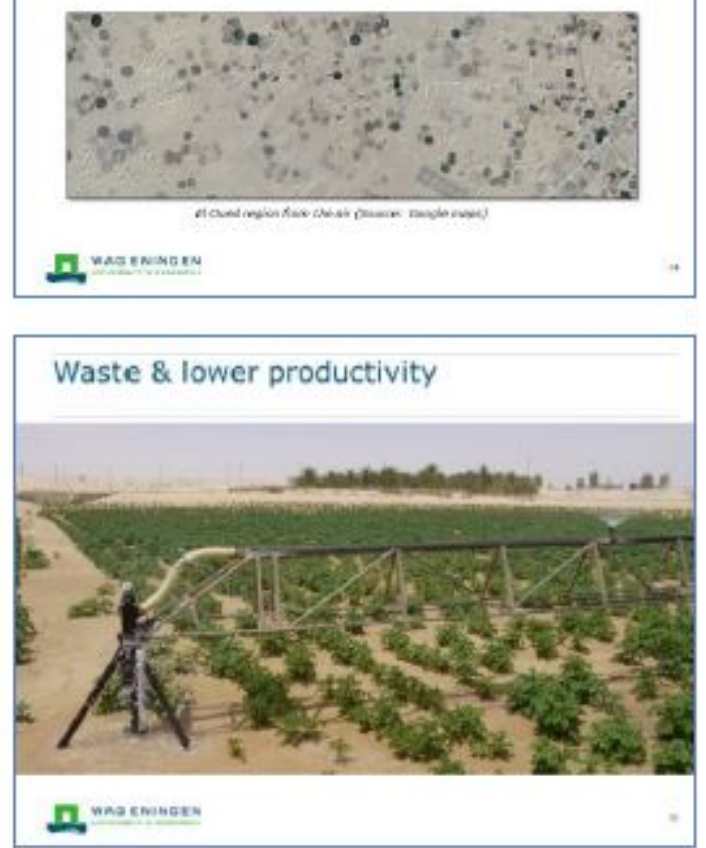

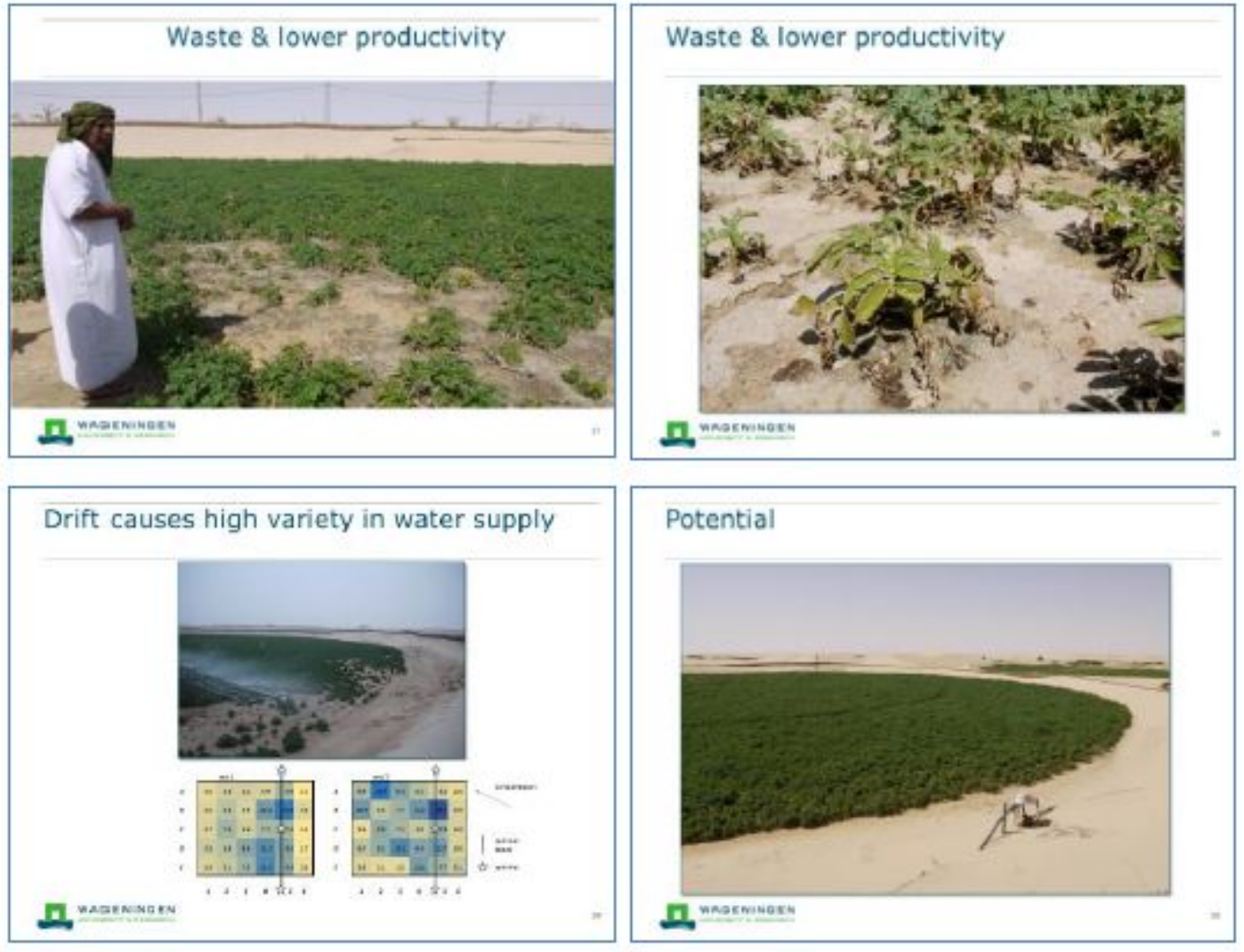

Objectives new demonstration project
- Saving water extraction and irrigation by monitoring
and control
- Lower the $\mathrm{CO}_{2}$ Footprint (water \& enecgy saving)
- Optimization fertilizer supply
- Intraduction better varieties
- Intraduction mechanization at planting and harvest
- Development of national roll-out plan for scaling-up
D. wasmeware

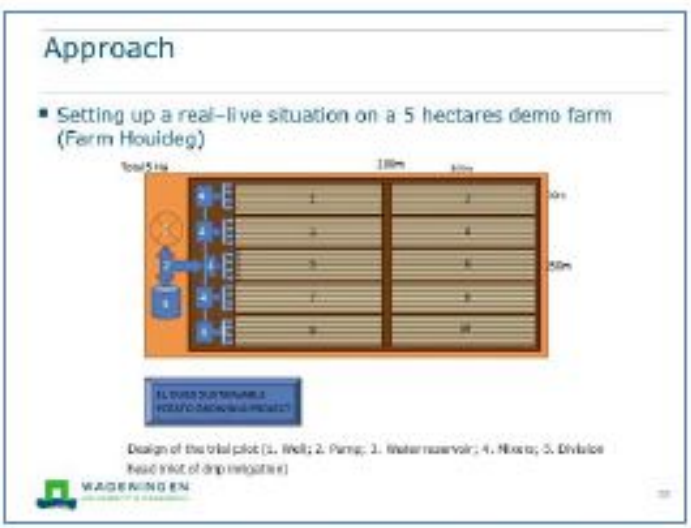

\begin{tabular}{|c|}
\hline Approach \\
\hline $\begin{array}{l}\text { - Introctuction of an underground fertigation system integrated } \\
\text { drip and fertilsation) }\end{array}$ \\
\hline - Introcluction high quality varietties with low woter footprint \\
\hline 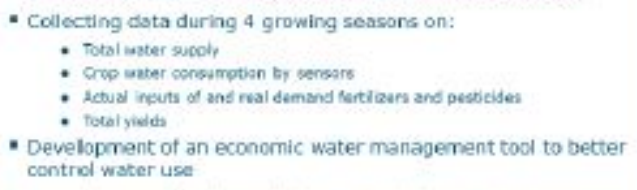 \\
\hline - Introcluction of mechanical planting and harvesting equipment \\
\hline $\begin{array}{l}\text { - Organisation of afferent workshops } \\
\text { ב- wasenwser }\end{array}$ \\
\hline
\end{tabular}

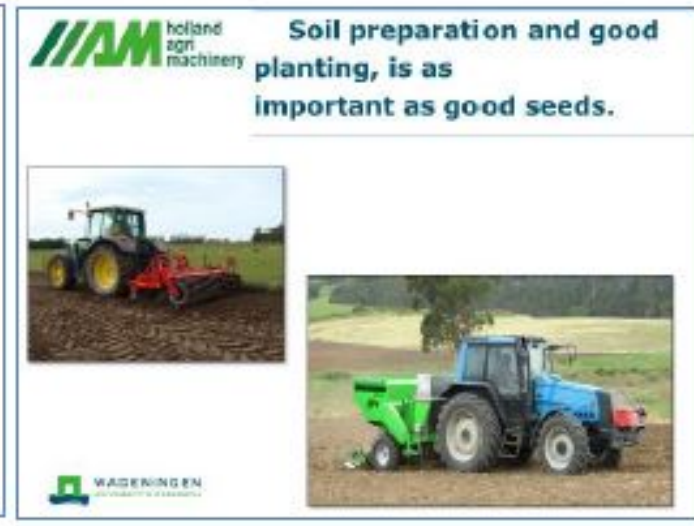



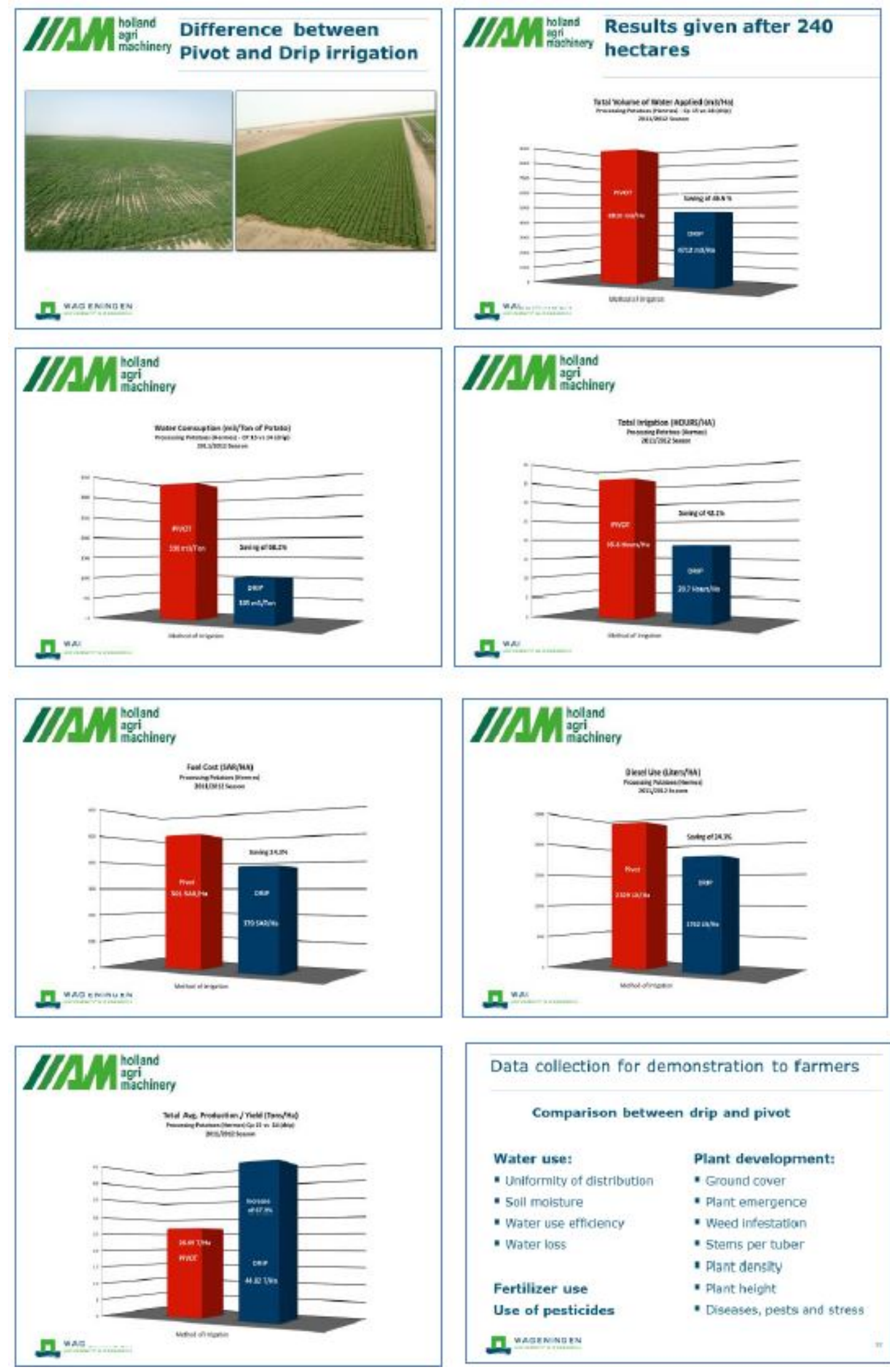

\begin{tabular}{|c|c|}
\hline Data collection for d & onstration to farmers \\
\hline Comparison betw & drip and pivot \\
\hline Water use: & Plant development: \\
\hline - Uniformity of distribution & - Ground cover \\
\hline - Soll moksture & - Plant emergence \\
\hline - Water use effidency & - Weed infestation \\
\hline - Water lass & - 5 temis per tuber \\
\hline & - Plant densiny \\
\hline Fertilizer use & - Plant height \\
\hline Use of pesticides & - Diseases, pests and stress \\
\hline D. & \\
\hline
\end{tabular}


Cooperation WUR < - > 3 Algerian universities?

- University of El Oued

- University of Biskra

- University of Ouargla

Memorandum of Understanding:

Strengthening of working relationship between the parties

D. Wasenenes

\section{Cooperation}

- How do we make this cooperation operational?

- Can we make concrete plans and appointments to start the cooperation today?

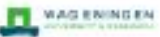

\section{Cooperation}

Aim:

- Facilitation of scientific knowledge exchange

- To encompass joint activities with rogard to oducational and zeientific cooperation

Form:

- Measurements in the demonstration projects

- Training use monitoring and control approach

- Involvernent in field visits farmers

- Resource sharing, student exchange, training, joint activities/projects

I. nasknessen

Thank you

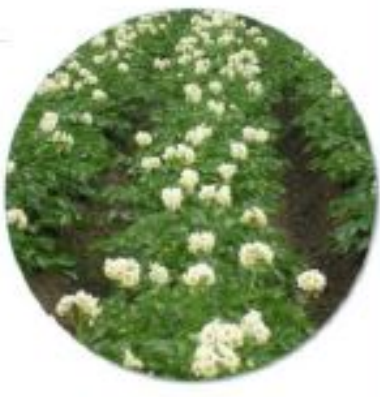

10. พmasmanos" 
Corresponding address for this report:

\section{P.O. Box 16}

6700 AA Wageningen

The Netherlands

$\mathrm{T}+31(0) 317480700$

Report WPR - 721
The mission of Wageningen University and Research is "To explore the potential of nature to improve the quality of life". Under the banner Wageningen University \& Research, Wageningen University and the specialised research institutes of the Wageningen Research Foundation have joined forces in contributing to finding solutions to important questions in the domain of healthy food and living environment. With its roughly 30 branches, 5,000 employees and 10,000 students, Wageningen University \& Research is one of the leading organisations in its domain. The unique Wageningen approach lies in its integrated approach to issues and the collaboration between different disciplines. 